\title{
The Invention of Taste
}




\title{
SENSORY STUDIES SERIES
}

\author{
Series Editor: David Howes
}

\begin{abstract}
As the leading publisher of scholarship on the culture of the senses, we are delighted to present this series of cutting-edge case studies, syntheses and translations in the emergent field of sensory studies. Building on the success of the Sensory Formations series, this new venture provides an invaluable resource for those involved in researching and teaching courses on the senses as subjects of study and means of inquiry. Embracing the insights of a wide array of humanities and social science disciplines, the field of sensory studies has emerged as the most comprehensive and dynamic framework yet for making sense of human experience. The series offers something for every disciplinary taste and sensory inclination.
\end{abstract}




\section{The Invention of Taste}

\section{A Cultural Account of Desire, Delight and Disgust in Fashion, Food and Art}

\section{Luca Vercelloni}

Translated by Kate Singleton 
First published 2005 by Bloomsbury Academic

Published 2020 by Routledge

2 Park Square, Milton Park, Abingdon, Oxon OX14 4RN

605 Third Avenue, New York, NY 10017

Routledge is an imprint of the Taylor \& Francis Group, an informa business

Copyright $\odot$ Luca Vercelloni, 2005 and 2016

English language translation @ Kate Singleton, 2016

Luca Vercelloni has asserted his right under the Copyright, Designs and Patents Act, 1988, to be identified as Author of this work.

All rights reserved. No part of this book may be reprinted or reproduced or utilised in any form or by any electronic, mechanical, or other means, now known or hereafter invented, including photocopying and recording, or in any information storage or retrieval system, without permission in writing from the publishers.

Notice:

Product or corporate names may be trademarks or registered trademarks, and are used only for identification and explanation without intent to infringe.

British Library Cataloguing-in-Publication Data

A catalogue record for this book is available from the British Library.

ISBN: HB: 978-1-4742-7360-2

PB: 978-1-3500-4801-0

Library of Congress Cataloging-in-Publication Data

A catalog record for this book is available from the Library of Congress.

Series: Sensory Studies Series

ISBN13: 9781-4742-7360-2 (hbk)

ISBN13: 9781-3500-4801-0 (Pbk)

Typeset by RefineCatch Limited, Bungay, Suffolk 


\section{CONTENTS}

Preface: Accounting for Taste vii

David Howes

Acknowledgments $\mathrm{xv}$

Introduction 1

1 The Success of a Metaphor 5

2 Pleasures and Morals 15

3 The Birth of Aesthetics and the Bifurcation of Tastes 39

4 The Arts of Happiness: A Journey Through Impure Tastes 73

5 The Economy of Taste in Consumer Society 95

Notes 159

Bibliographies 177

Index 191 


\section{Preface: Accounting for Taste}

\section{David Howes}

This book is about one of the more fascinating developments in the cultural history of the senses: the invention of "taste." It is written by an interdisciplinary scholar of the first order, a man who moves comfortably across the disciplines of history, philosophy and sociology. The fact that Luca Vercelloni is also a brand expert, and founder of the international consulting firm Brandvoyant, gives him an added insight into contemporary tastes. His account is accordingly a "history of the present," an archeology of the genesis and proliferation of a peculiarly modern sensibility.

To give some historical background to this account, Aristotle identified taste as one of the five senses, but characterized it as "a form of touch," hence lacking autonomy. In the ensuing centuries, as the idea of a hierarchy of the senses was elaborated, taste was grouped with the "lower," "bodily" senses of touch and smell, as opposed to the "higher," "intellectual" senses of sight and hearing. Due to its association with self-indulgent sensuality, it was subject to extensive moral regulation. ${ }^{1}$ To be a gourmand-that is, one who revelled in the pleasures of the palate-was to commit the sin of gluttony, one of the seven cardinal sins. With the increasing secularization of society in modernity, gustatory indulgence would lose much of its negative connotation and associations. Vercelloni relates, in one of the many revelations of this book, that a number of former "sins" were in effect recast as "virtues": the sin of vainglory was reconstituted as personal ambition, the sin of sloth was recast as leisure, and the gluttonous delight in fine foods was converted, on the one hand, into gastronomy, and, on the other, metaphorized as the sense of discernment, of beauty. According to Vercelloni, this transformation of vices into virtues was a key element in the coming to be of modern society.

The transformation or bifurcation in the meaning of taste, which appears to have originated in sixteenth-century Italy or seventeenth-century Spain (there is some dispute), unfolded gradually and reached its apogee in the eighteenth century. That century has come down to us under various names: the "Age of Reason" or "Enlightenment," but also the "Age of Sensibility," and, of course, the "Century of Taste." The German philosopher Alexander von Baumgarten played a role in the doubling or reconstitution of taste as the aesthetic sense by introducing the term aesthetic. This term was derived 
from the Greek aisthēsis (meaning sense perception) to refer to the capacity to discern the unity in multiplicity of sensible qualities, without recourse to reason. The new "aesthetic" sense was accorded a variety of names in English until, thanks to the interventions of Alexander Pope and David Hume, it became known as taste. ${ }^{2}$ However, it is another German philosopher, Immanuel Kant, to whom we owe the most influential and indeed transcendental account of this new faculty, as elaborated in the Critique of the Power of Judgment.

Why taste? Vercelloni asks. Why not refer to this newly-theorized sense of beauty as a "third eye" or "inner ear"? It would appear that what commended the metaphor of taste to the thinkers of this period was the presumed spontaneous and pre-rational as well as subjective character of this sense. De gustibus non est disputandum- "there is no accounting for taste," as the saying went, with the implication that in this field "to each his own" applies. This construction agreed with the rising tide of individualism, the cult of sensibility, and the burgeoning influence of an empiricist mindset that undermined the Platonic idea of Beauty. Henceforth, the experience of beauty could only be a matter of perception, not an objective quality.

It was against this backdrop that the term taste was metaphorized-i.e., borrowed from the sphere of the palate and applied to the realm of aesthetics. In the course of this transposition it was also severed from sensory pleasure. The purification of taste was the work of Immanuel Kant. Vercelloni emphasizes that the puritanical and totalitarian, though resolutely egalitarian, account of taste as based in "disinterestedness" proposed by Kant was but one construction among others, even if it would prove the most enduring. There was also the more hedonistic and conciliatory though distinctly élitist account proposed by Hume, which centred on the sensibility of the educated gentleman or "Man of Taste." For Kant, however, the judgment of taste-as related particularly to the fine arts-had to be disinterested, universal, necessary and pure, which is to say impermeable to pleasure and need. Hence the famous line: "whoever declares something to be beautiful wishes that everyone should approve of the object in question." 3 In this way, beauty (or the experience of "spiritual" pleasure which derives from it) was isolated, sealed off from the body, and what is merely agreeable or useful, and came to center on the elevation of the mind. In a new variation of the religious strictures on sensuality, everything turned on the "continence of desire" or taming of inclinations, the "snuffing of sensuality," as Vercelloni puts it, in the cause of intellectual refinement.

The elevation of sensibility decreed by Kant was motivated by ideology. It was tied to the Enlightenment dream of a society based on the principle of universal rights and mutual respect in which each subject "gives the law" to him- or herself voluntarily. On this account, taste (aesthetic taste, that is) promotes upward integration and the edification of the subject, in contrast to the ancien régime, where taste was the preserve of an élite, modeled on the unrestricted gratifications of the aristocracy. However, there was a contradiction embedded in this construction. On the surface it appeared to 
be open to every man, and held out the possibility of consensus, the emergence of a shared sensibility. But this construction obscured the underside of the judgment of taste, which entailed the rejection of all that is facile, childish, vulgar or "primitive." Viewed from this angle, taste can also be seen as a force for discrimination downwards. To have taste, a certain savoir vivre, as the bourgeoisie would come to define it, could serve as a source of "cultural capital," 4 which was the very antithesis of disinterestedness as conceived by Kant.

Vercelloni is adept at exposing the contradictions embedded in the Kantian doctrine of "pure" taste, with its emphasis on controlling (or sublimating) desire "for the betterment of sensibility and manners." But he does not stop there. Rather, he plunges into an exploration of various "lesser" manifestations of taste, which developed as the term spread to encompass discernment in other domains besides the fine arts—most notably food and fashion-on its way to becoming the most ubiquitous disposition of the nascent consumer culture. The taste of the palate and taste in clothing were dismissed or belittled by Kant on account of their seemingly ephemeral and whimsical character-their lack of continence and consistency. But these "impure" tastes, with their accent on frivolity or excess (i.e. distance from necessity) would win out over the aesthetics of solemnity and distance championed by Kant on account of their link to the post-Enlightenment penchant for selffashioning and privileging of personal identity over social equality.

To understand this shift entails delving into the other meaning of the adage De gustibus non est disputandum, which is hidden from us today because of our ignorance of the premodern cosmology on which it was based. Vercelloni's archeology of gustatory perception indicates that the reason there could be no disputing taste was due to medieval dietetics. The latter regimen was informed by humoral theory, which held that the temperament of each individual was determined by the balance of humors in the body, which, in turn, was often assigned an astrological basis. The task of the cook was to blend the hot or cold, wet or dry qualities of the food served up to match or modulate the temperament of his patron. In this view, there was nothing temperamental (in a modern sense) or fickle about taste. Individual tastes were cosmologically conditioned, hence given in the order of things, intrinsically incommensurable, and therefore impervious to disputation.

Of note in this connection was the curious phenomenon of the "silence of taste" ${ }^{5}$ in the first cooking manuals and recipe books (dating from the mid-seventeenth century) which contained the seeds of the discourse of gastronomy. The authors of these books did not rationalize their concoctions in terms of the pleasures they afforded (that would have been immoral), but referred instead to the Providence of the Creator, or the therapeutic benefits of different foodstuffs. Taste (gustatory taste, that is) was muted, and, aside from providing recipes, the food writing of the period dwelt mainly on the rules of comportment (table manners) and the visual order or architecture of the banquet, as if the repasts concerned were intended more as feasts for the eyes than the palate. It was not until the latter half of the eighteenth 
century that the cult of good food and elegant dining, with Versailles as its epicentre, became established, and the thoroughly modern figure of the gourmet or gastronome arrived on the scene.

The role of the gastronome, as the name implies, is "to rule over the appetites of others." Unlike the seventeenth-century authors of cookery books, who often wrote in the third person, the gastronome writes in the first person. He uses his personal taste to sample and pronounce judgments, which can then be followed by others (i.e. status seekers). The whole point of the gastronome's existence is to make an exception of himself, to "show off his unparalleled sensory refinement." ${ }^{6} \mathrm{His}$ is a discourse that eschews universality, being founded on the pleasures of diversity, and goes to great length in the pursuit of detail. Gastronomic writing evoked "voluptuous experience, titillating the tastebuds and promoting lubricious salivation." Kant-as well as the Church Fathers-would have been aghast.

The literature of gastronomy never amounted to more than a minor literary genre, disdained by philosophers, but its "appetising eloquence" proved disarming - and charming. Most importantly, according to Vercelloni, it was addressed to an audience "desirous of discovering exactly what it should experience, prefer and appreciate," and provided "a way of enclosing individual sensibility." This function was particularly important in the heady days after the Revolution of 1789 when restaurants sprang up all over Paris, manned by the chefs who had been put out of work by the execution of their patrons. Middle-class restaurants provided the bourgeoisie with an institutional context for self-fashioning, and the gastronome provided them with a compass and language for their desires. Another key supplier of the means of individuation that arose during this period was the fashion house. ${ }^{7}$ Like the restaurant, it provided its clients with a range of options from which each could choose. In this way, haute cuisine and haute couture, which were both inspired by and derived from court society, were commercialized and rendered respectable diversions as "vehicles for the principle of personal style." From this perspective, the most salient outcome of the revolutionary period was thus not so much the right to equality as the "right to desire," to pursue happiness. The "arts of pleasing"-gastronomy and fashion-now vied with the fine arts as avenues for the discovery and refinement of individual sensibility.

This brings us to the final chapter of Vercelloni's book, "The Economy of Taste in Consumer Society," which covers the period from the beginning of the nineteenth century down to the present. In the section on "Bewitching Commodities," Vercelloni traces the trajectory from the first magasins de nouveautés and arcades to the grands magasins, such as the Bon Marché department store, and universal exhibitions that served as sites for the "democratization of luxury" and idealization of commodities. This period witnessed the transformation of capitalism from a mode of production predicated on self-discipline and sensory restriction into a mode of presentation-seduction (e.g. window displays, advertising) and consumption, premised on self-indulgence and sensory enticement. 
In "Ease and Progress," Vercelloni describes how the shock that came in the wake of the democratization of luxury and the onslaught of commodities, the proliferation of tastes, and the rise of mass taste provoked a rearguard action. This came in the form of the Modernist Movement. The proponents of Modernism denigrated ornament, denounced the spread of "feminine taste" (on account of its alleged frivolity and excess), and decried anything that was easy, or comfortable. They spoke in the name of rationality, progress and efficiency with such slogans as "form follows function" and "less is more." Kant would have approved. The "enlightened" ascetic aesthetic of contemplation and distance reasserted itself - as can be seen in the linear purity and grey predictability of the modern office tower, or the home designed as a "machine for living." Then Modernism lost its hold, became just one style among others, and was even outstripped by the style of streamlining (e.g. the tailfins of a 1950s Chevrolet, which had as much to do with ornamentation as function).

In a section entitled "The Gallery of Iconoclasm," Vercelloni relates how modern art (the art of the avant garde) was born with "the explicit intention of not pleasing." Divorced from aesthetics (as conventionally understood), it became an outlet for "the spirit of desecration" and scandal. This in turn is exemplified by Marcel Duchamp's submission of "Fountain," which consisted of a urinal turned on its side, as an exhibition for the Salon of Independent Artists in New York in 1917. By taking the lowliest of everyday objects (a readymade at that) and promoting it as art, Duchamp upset and made a mockery of the established norms of art. (While rejected at the time, Duchamp's gesture has been growing in stature ever since.) Art after Duchamp would emphasize individual genius (or self-referentiality) over beauty and skill. As for taste, "Taste is no longer the faculty for recognizing an abstract ideal, a shared goal to which all ages in history were supposed to draw closer. [Instead, it] is Style that commands, the prototype of all individual predilections: gratuitous, revocable, and yet at the same time irresistible and inexplicably contagious."

In "Tattooed Man," Vercelloni delves deeper into the election of style as a dominant ideal of taste in the twentieth century as exemplified by the figure of the fashion designer. The fashion designer "lays down the laws of vanity": his or her signature helps people in their choice of what to wear by canonizing (a particular) taste or style. Designers such as Christian Dior and Pierre Cardin have also drawn up a vast range of previously unrelated commodities-"from garments to cosmetics, chocolate, furniture and appliances"-into the realm of fashion, under the system of brand licensing, investing them "with their personal charisma to further their commercial success." The exponential growth of the style trade, which centres on "the metamorphosis of brands into the symbols and mirages of lifestyles," can no longer be explained in terms of competition between social classes, "trickledown" effects, and the like, because designers now increasingly take their inspiration from the streets (e.g., grunge, hiphop). Rather, the "irresistibility of fashion lies in its ability to foment desires and encourage the compulsion 
for luxury, or at least what is superfluous, in the name of self-realization." Sadly, being a follower of fashion is no guarantee of happiness or "material grace." It just as often issues in disappointment and depression, "the empty chimera of unfulfilled promise."

In the final section of Chapter 5, Vercelloni turns his attention to the "nutritional prosperity" that the industrialization of the food chain and globalization have wrought. Ours is an age of overabundance that holds out the promise of unlimited freedom of choice. It is no longer the case that you are what you eat; instead you eat (or at least try to eat) what you would like to be. Food choice is no longer conditioned by cultural background and family habit, but rather by self-affirmation and body-image. However, this ostensible gastroutopia has created more hunger, not less, and instituted an ever-growing rift between control and indulgence, between the duties involved in looking after one's health and giving in to temptation. Whence the proliferation of diets promising nutritional salvation and longevity, and all the new gastronomies of pleasure beginning with the nowvelle cuisine of the 1970s, which heralded a return to "nature," the primacy of ingredients over processing, and "lighter," "simpler" fare (in contrast to the monumental, pompous dishes of haute cuisine). Also of note in this connection is the phenomenon of "gastronomic restoration"- -the counter-revolution in taste that has put pasta and olive oil (essential ingredients of the Mediterranean diet), daily doses of red wine (the French elixir) and "gastronomic treasures" (the "typical" products of a given terroir) back on the "High Table of Comestibles." Of course, these timehonored traditions are no less invented than the latest food fad, but we delight in the reassurance they provide just the same.

Summing up, Vercelloni writes: "Impure, changeable and concupiscent though it may be, taste is the true engine of consumer society, the organ of individual preferences and the tool with which people build up their personalities. Spurned by educated aesthetics, it has its revenge in ratifying an inalienable right: the search for human happiness; in other words the right to desire."

In this account, I have provided only the briefest sketch of the many twists and turns of Vercelloni's own account of the "odyssey" of taste. The map he provides is vital reading for anyone-taste-maker, cultural historian or ordinary consumer-interested in understanding how tastes are invented and diffused in today's society. He gives us access, in a way which is rare in contemporary cultural history, to the big picture, in all its eclectic detail. When this work was first published in Italian in 2005, it attracted much critical acclaim. Vercelloni nevertheless revised it extensively for this English edition. He was fortunate to find Kate Singleton to translate his work, for she has succeeded magnificently at transposing the author's many subtle, and deeply perspicacious, turns of phrase into their English equivalents.

Just as the history of sight is not synonymous with that of painting, and the history of smell must needs depart from that of perfume, so the history of taste could never be confined to the history of cuisine. The extent to which taste has spread since its metaphorization, and become the ground 
for so many struggles (between classes, between sexes) in so many domains (fashion, food, art, architecture, design), across so many senses (there is taste in music as well as food), the paradoxical way in which taste has been universally adopted as a means for individual expression and gratification and serves as the engine of consumer society-point to the necessity for a cultural account of taste. It is such an account that is provided in this book, giving the lie to the still commonplace expression De gustibus non est disputandum.

\section{Notes}

1 For excellent accounts of the moral regulation of the senses in the early modern period see W. de Boer, "The Counter-Reformation of the Senses," in A. Bamji, G. Jansen and M. Laven (eds), The Ashgate Research Companion to the Counter Reformation, Ashgate Publishing, Farnham, Surrey, 2013, pp. 243-60; and C. Classen, The Deepest Sense: A Cultural History of Touch, University of Illinois Press, Champaign, 2012.

2 Other terms for this new faculty included the "inner sense," the "seventh sense" and the "sense of beauty." The invention—or, discrimination—of new senses in the eighteenth century is a fascinating topic, which calls out for more investigations like the present one. See D. Howes, "Introduction," in D. Howes (ed.), The Sixth Sense Reader, Berg, Oxford, 2009.

3 I. Kant, Critique of the Power of Judgment, Cambridge University Press, Cambridge, 2000, p. 121.

4 P. Bourdieu, Distinction: A Social Critique of the Judgement of Taste, Harvard University Press, Cambridge, MA, 1984.

5 V. von Hoffman, Goûter le monde: Une histoire culturelle du gồt à l'époque moderne, Peter Lang, Brussels, 2013.

6 Kant did not approve of people making exceptions of themselves in aestheticsor in ethics. See G. Grant, English-Speaking Justice, House of Anansi Press, Toronto, 1985.

7 Vercelloni quotes Lipovetsky regarding how the rise (and volatility) of fashion is related to "the awareness of being an individual with a specific destiny, the desire to express an original identity and the cultural celebration of personal identity." For Vercelloni himself, however, the matter is not just one of individuation but also one of feminization - the feminization of taste, "the predominance of the female sensibility." See especially his discussion of the Great Sacrifice and the Great Revenge.

\section{References}

Boer, Wietse de, "The Counter-Reformation of the Senses," in Alexandra Bamji, Geert Jansen and Mary Laven (eds), The Ashgate Research Companion to the Counter Reformation, Ashgate Publishing, Farnham, Surrey, 2013, pp. 243-60. 
Bourdieu, Pierre, Distinction: A Social Critique of the Judgement of Taste, Harvard University Press, Cambridge, MA, 1984.

Classen, Constance, The Deepest Sense: A Cultural History of Touch, University of Illinois Press, Champaign, 2012.

Grant, George, English-Speaking Justice, House of Anansi Press, Toronto, 1985.

Hoffman, Viktoria von, Goûter le monde: Une histoire culturelle du gồt à l'époque moderne, Peter Lang, Brussels, 2013.

Howes, David, "Introduction," in David Howes (ed.), The Sixth Sense Reader, Berg, Oxford, 2009, pp. 1-52.

Kant, Immanuel, Critique of the Power of Judgment, Cambridge University Press, Cambridge, 2000.

David Howes

Series Editor

30 September 2015 


\section{Acknowledgments}

Though this book aims to trace a cultural history of taste through different ages, conceptually it starts from the end: from my own empirical observations of consumer behavior, attitudes and aspirations over a period of three decades and in around forty countries. During my research it became increasingly evident that geography, age, gender, social background and education influence and shape people's varied lifestyles and preferences, dreams and desires. Culture is the yardstick and engine of the apparently volatile kaleidoscope of human tastes.

When culture is freed from the artificial confines of academic debate and is extended to embrace material and social phenomena, it also provides the only reliable standpoint for appraisal of the evolution of taste as a social fact.

Several important books have been written about taste, and of course I am indebted to Bourdieu, Croce, Dorfles, Elias, Simmel, Sombart, Tatarkiewicz and many other eminent scholars who have dealt with the topic. But I always I felt that something was missing. The subject required a comprehensive overview that could explain the outwardly irrational manifestations and whimsical practices of taste within the fields of arts, fashion, cuisine, and entertainment. And, above all, why all these fields are subject to the same concept-taste. Analysis of a huge quantity of facts and figures persuaded me that individual taste represents a cultural construct, an implicit self-portrait that relates our identity to that of others in an ongoing process of emulation and differentiation, sense of belonging and aspiration to change. Such are the guidelines that I have used in my exploration of the different stages of the history of taste.

I spent five years writing the first Italian edition of the book, and another five revising and enriching the text for the present English edition. I am particularly grateful to my friend Sebastiano Cossia Castiglioni, a connoisseur of fine arts, wine and cuisine, who encouraged me to accomplish this double effort and provided me with precious advice. I am also very grateful to Kate Singleton who patiently and skillfully accomplished the polished and impeccable English translation of the text. Special thanks also go to Serena Feloj who helped me with a meticulous bibliographic revision. Lastly, I am beholden to Jennifer Schmidt of Bloomsbury, who first acknowledged the value of the manuscript, and I especially am grateful to professor David Howes for his enthusiastic support of the publication and for agreeing to write the insightful preface. 


\section{Introduction}

The history of successful ideas is full of discontinuity and metamorphosis. And that of taste is no exception. For such twists and turns actually help promote what is new, widening its relevance and sphere of acceptance, changing habits and modifying representative images.

The odyssey of taste is swathed in enigma and paradox, starting with the original meaning of the word. As one of the five senses, taste is a natural faculty, an integral part of our biological constitution. However, it is also acquired, and thus not entirely natural: an expression of habit, tradition and the civilizing process no less than of corporeity. Taste is stimulated by hunger and the instinct for survival, but also by the seduction of value and privilege. It captures and reveals human pleasure, starting with the primordial need to satiate hunger and thirst. It is adaptable, variable and subject to influence, in relation to the variety and availability of food and drink. The sense of beauty that guides visual taste presents much the same problem, in that it is spontaneous and unintentional, and yet at the same time susceptible to improvement, refinement and education. Though it tends to conform to models imposed by society, it can also vary according to culture and historic period. Thus both gastronomic and aesthetic taste are characterized by the same basic ambivalence.

This essential contradiction is part and parcel of the history of taste, perceived as an expression of a sensibility that can be communicated, learned and perfected. On this account taste can also claim to be an uncontestable form of knowledge, however partial, imperfect and elusive it may appear to be.

Another feature intrinsic to the idea is the stratification of meanings and spheres of experience inherent in its development. Taste comes across as pooled knowledge, as an accumulation that absorbs and reshapes earlier conceptions rather than erasing them. When the term is used to refer to something immaterial, the original sensorial meaning acts as an analogy that supports and divulges the new semantic content. Even when taste invests an exclusively spiritual sphere, its relationship to the palate remains, by way of difference and contrast.

When knowledge and experience are stratified, they inevitably interweave and do so with many other threads of history. In particular, with the history 
of art and its contemplative function, which both have a great deal to do with taste as a metaphor. But also with the history of costume and fashion, whose evolution mirrors the loosening of moral constraints; with the invention of good manners; with the development of luxury; with the stylization of vanity and appearance-all of which are an integral part of the metaphor in its widest acceptance. As for the history of ideas and ideology, it engages taste within the overall perspective of modern subject's spiritual prerogatives. Lastly there is the history of cuisine and gastronomy, which tends towards the refinement of the palate and the portrayal of taste as a manifestation of privilege and cultural accomplishment.

At this point it is clear that only an "eclectic" reconstruction of the history of taste can throw light on the points of contact, mutual influence and fusion that have characterized its parallel lives. Such an approach has the advantage of transcending the disciplinary confines and interpretative constraints typical of the specialist perspective. Its originality lies in its ability to cross borders and provide new insights.

The first of the five chapters of this book is devoted to the invention of the metaphor that transformed a bodily sense into a faculty of the mind. Scholars of the past have posited a number of explanations for this phenomenon, but most of them leave many questions unanswered. Why exactly did taste become a metaphor? What counter-effects did this semantic development have on artistic perception? What were the conditions that made this side-step possible? As we shall see, the famous medieval adage de gustibus non est disputandum helped mediate the transition, but acquired a whole new meaning in the process.

Chapter 2 reconstructs the main stages in the "moral history" of taste. Starting with the manifestations of "weakness" criticized by ancient Greek and Roman commentators, it traces the secularization of the capital sins to focus on the birth of sumptuous cuisine and the necessary refinement of appetites. In so doing, it throws light on how the spread and acceptance of an idea paved the way for the expression of predilection, and thus the evolution of customs and the development of self-awareness.

In Chapter 3, thoughts are centered on the main theories of taste propounded by philosophers once the phenomenon had spread from the sphere of the body to that of the mind. Though many authors have argued that the whole process was both natural and intrinsically excellent, it is our opinion that the Kantian divide between palate and mind is anything but the objective fruit of theoretical endeavor. To the contrary, it is the necessary corollary of Enlightenment equalitarianism.

Chapter 4 takes a look at two "lesser" manifestations of taste: gastronomy and fashion, which continue to exercise considerable influence despite Kant's evident disapproval. Until recently, in fact, academic study spurned these two spheres of activity, which were deemed extraneous to serious literature. The chapter also proposes possible explanations for just why this should have been so.

Finally, Chapter 5 deals with the various different manifestations of taste 
in contemporary society, where the term implies "good taste" and is thus a measure of social distinction. This in itself means redefining the phenomenon and establishing a new framework for its applications. The commercialization of taste, the aesthetic straitjacket imposed by architecture and design, the rejection of common criteria for appreciating modern art, and the wide range of identities offered by ubiquitous fashion all relate to the paradoxes of taste during the twentieth century. The chapter then examines taste relating to the palate in an age when such sensorial perception has been irreversibly remodeled and transformed by ideological and conceptual constraints. The chapter ends by providing an account of the triumph of pleasure in consumer society, with its power to manipulate the development of taste, from its first appearance as a metaphor through to the present day. 


\section{NOTES}

\section{Chapter 1 The Success of a Metaphor}

1 B. Croce, Storia dell'età barocca in Italia, Laterza, Bari, 1929.

2 F. Schümmer, Die Entwicklung des Geschmackbegriff in der Philosophie des 17. und 18. Jahrhunderts, "Archiv für Begriffsgeschichte," 1: 120-41, 1956.

3 U. Franckowiak, Der gute Geschmack. Studien zur Entwicklung des Geschmackbegriff, Fink, Munich, 1994.

4 R. Klein, Form and Meaning. Essays on the Renaissance and Modern Art, Princeton University Press, Princeton, 1981.

5 A. Hauser, The Social History of Art, Routledge, London, 1999, p. 68.

6 Hauser, see note 5, pp. 38-9.

7 Hauser, see note 5 , p. 48.

8 A.K. Coomaraswamy, Christian and Oriental Philosophy of Art, Dover Publications, New York, 1956, p. 108.

9 A.K. Coomaraswamy, "A figure of speech or a figure of thought?," in A.K. Coomaraswamy, Selected Papers. Traditional Art and Symbolism, Bollingen, Dehli, 1977, p. 13.

10 Coomaraswamy, see note 8, p. 16.

11 Coomaraswamy, see note 8, pp. 64-5.

12 Coomaraswamy, see note 9, p. 14.

13 A.K. Coomaraswamy, “Ornament," in Coomaraswamy, see note 9, p. 253.

14 B. Croce, Estetica come scienza dell'espressione linguistica generale. Teoria e storia, Adelphi, Milan, 1990, p. 235.

15 Croce, see note 14, p. 235.

16 Croce, see note 14, p. 239.

17 B. Croce, "Iniziazione all'estetica del Settecento" (1933), in B. Croce, Filosofia. Poesia. Storia, Ricciardi, Milan and Naples, 1951, p. 410.

18 In the edition of 1612 and 1623, the only meaning attributed to taste is that of “pleasure, delight, appetite." In the 1691 edition, this interpretation is traced back to the Latin terms delectatio and voluptas, whereas the first meaning of taste is given as "try" (libatio). Moreover, the same edition ushers in the expression "good taste," restricted to the practical sense that Croce attributed to Gracián: "you can talk about having good taste in any sphere: in other words, to be intelligent." The Latin circumlocutions adopted to clarify the matter were peritiam habere, probe callere, acri iudicio pollere, in other words to have 
practical knowledge, great skill or depth of judgment. The 1738 edition maintained the same approach, but with the additions of "bighly" before the word "intelligent" and "intended as good."

19 Zuccolo, quoted by Croce, see note 1, p. 166, my italics.

20 Voltaire, "Goût," in Encyclopédie ou dictionnaire raisonnée des sciences, des arts et des métiers, vol. VII, Livourne, 1778, pp. 746-7. At the end of this entry, Voltaire reins in the universal extension of the metaphor: "There are many countries-he writes-as yet untouched by taste. They are those in which society has not developed, in which men and women do not resemble each other, or where certain arts such as sculpture and painting are forbidden by religion. Where there is little society, where the spirit is cramped, its stimulus is blunted: what is lacking is the matter from which taste is formed. This is why the Asians have never possessed well-made works of any sort and why taste has been the exclusive patrimony of certain peoples of Europe."

21 The term is used to refer to metaphors that are absorbed into everyday language out of necessity, without appearing to be overly manipulated: the neck of a bottle, the leg of a table, the head of a pin, and so on. The extended meaning of the word taste went one step further, however, ultimately affecting the original sense of the term.

22 "Just as the gourmet recognizes and immediately perceives the mixture of two liquors, so the man of taste, the connoisseur, will be aware at first glance of the mixing of two styles" (Voltaire, see note 20).

23 Voltaire, see note 20.

24 Montesquieu, Essai sur le goût, 1757.

25 Voltaire, see note 20.

26 Croce on Du Bos, in Estetica, see note 14, pp. 244-5.

27 Croce on Home, in Estetica, see note 14, p. 601.

28 A. Laurent, De l'individualisme, enquête sur le retour de l'individu, Presses Universitaires de France, Paris, 1985.

29 Clearly the epistemological decline of the disputatio, its diminishing relevance to teaching and its demise as a method for settling complex questions all contributed to the loss of validity of the medieval adage.

\section{Chapter 2 Pleasures and Morals}

1 Tacitus, Annals, XVI, 18. Elegantia is the Latin term that best sums up what we mean by taste today.

2 P. Veyne, "The Roman Empire," in P. Ariès and G. Duby (eds), A History of Private Life: from Pagan Rome to Bysantium, Harvard University Press, Cambridge, MA, 2003, p. 123.

$3 \mathrm{~F}$. Revel, Un festin en paroles. Histoire littéraire de la sensibilité gastronomique de l'Antiquité à nos jours, Plon, Paris, 1995, p. 53.

4 See. J. Davidson, Courtesans and Fishcakes. The Consuming Passions of Classical Athens, Fortuna Press, London, 1998. 
5 B. Lançon, Rome in Late Antiquity: Everyday Life and Urban Change, Routledge, London, 2001.

6 U.E. Paoli, Vita romana. Usi, costumi, istituzioni, tradizioni, Mondadori, Milan, 1990, p. 96.

7 R. Flacelière, Daily Life in Greece at the Time of Pericles, Macmillan, New York, 1965, p. 151.

8 See C.J. Berry, The Idea of Luxury. A Conceptual and Historical Investigation, Cambridge University Press, Cambridge, 1994, ch. 3.

9 R. Muchembled, L'invention de l'homme moderne. Culture et sensibilités en France du XVe au XVIIIe siècle, Fayard, Paris, pp. 458-9, 1994.

10 See N. Elias, The Court Society, University College Dublin Press, Dublin, 2006; and N. Elias, The Civilizing Process, Blackwell, Oxford, 2000.

11 C. Casagrande and S. Vecchio, I sette peccati capitali. Storia dei peccati nel Medioevo, Einaudi, Turin, 2000, p. XII.

12 M. Onfray, "Sept péchés capitaux," in G. Viatte, D. Ottinger and M. Onfray, Les Péchées capitaux, Éditions du Centre Pompidou, Paris, 1996, p. 44.

13 Onfray, see note 12, p. 48.

14 See W. Sombart, The Quintessence of Capitalism, Routledge, London, 1930.

15 Elias, The Court Society, see note 10.

16 W. Sombart, Luxury and Capitalism, University of Michigan Press, Michigan, 1967.

17 Veyne, see note 2, p.179.

18 Elias, The Court Society, see note 10.

19 Sombart, see note 16 .

20 Sombart, see note 16 .

21 Sombart, see note 16.

22 Sombart, see note 16.

23 See B. de Mandeville, The Fable of the Bees: or, Private Vices, Public Benefits (1723).

24 Gregorius Magnus, quoted by Thomas Aquinas in Quaestiones disputatae De malo, q. 14, a. 1.

25 See Thomas Aquinas, Summa theologiae II-II, q. 148, a.6 and Quaestiones disputatae De malo, q. 14, a. 4

26 Thomas Aquinas, Summa theologiae, see note 25, q. 150, a.2.

27 Thomas Aquinas, Summa theologiae, see note 25, q.149. a.1.

28 Quoted in Thomas Aquinas, Quaestiones disputatae, see note 25, q. 148, a.4

29 Thomas Aquinas, Quaestiones disputatae, see note 25, q. 148, a.4.

30 Thomas Aquinas, Quaestiones disputatae, see note 25, q. 14, a.3.

31 Thomas Aquinas, Quaestiones disputatae, see note 25.

32 It is worth pointing out that in French, the term gourmet originally referred to wine tasters, whereas gourmand meant "glutton." See J.-L. Flandrin, "Distinctions through taste," in P. Ariès and G. Duby, A History of Private Life: Passions of the Renaissance, Harvard University Press, Cambridge, MA, 2003. 
33 Thomas Aquinas, Summa theologiae, see note 25, q. 150, a.2.

34 The faculties of the soul are the consequence of the temperaments of the body is the title of a famous work by Galen.

35 Galen, Quod animi mores corporis temperamenta sequantur.

$36 \mathrm{M}$. Jeanneret, Des mets et des mots. Banquets et propos de table à la Renaissance, Corti, Paris, 1987, p. 80.

37 B. Platina, Il piacere onesto e la buona salute, Einaudi, Turin, 1985, pp. 17-18.

38 "The civilising of appetite, if we may call it that, appears to have been partly related to the increasing security, regularity, reliability and variety of food supply. But just as the civilising of appetite was entangled with several other strands of the civilising process, including the transformation of table manners, so the improvement of food supplies was only one strand in a complex of developments within the social figuration which together exerted a compelling force over the way people behaved. The increased security of food supplies was made possible by the extension of trade, the progressive division of labour in a growing commercial economy, and also by the process of state-formation and internal pacification" (S. Mennell, All Manners of Food. Eating and taste in England and France from Middle Ages to the Present, University of Illinois Press, Urbana and Chicago, $1996^{2}$, p. 32).

39 N. Elias, The Civilizing Process, see note 10.

40 M. Montanari, La fame e l'abbondanza. Storia dell'alimentazione in Europa, Laterza, Rome and Bari, 1993, p. 75.

41 Montanari, see note 40, pp. 106-8.

42 Mennell, see note 38 , pp 33-4.

43 The very term gradually took on a different meaning: "Delicacy" initially meant the quality of being addicted to sensual pleasure and encompassed by lust and gluttony, but mostly gluttony [... ] Delicacy was the excessive immersion in the bodily pleasure-especially that of the palate-to the exclusion of all else. But slowly the notion of delicacy got caught up in the civilization process; it got refined. Instead of referencing sin, it now referenced a delicacy of taste, a sensitivity to the elegant, to the pleasing, to refined and subtle sensation, so that from the immoral beginnings in gorging, it ends by the time Hume is writing in the first half of eighteenth century, marking feelings of modesty, and the sense of propriety, and a delicate regard for the feeling of others" (W.I. Miller, "Gluttony," in R.C. Solomon (ed.), Wicked Pleasures, Rowman \& Littlefield, Lanham, 1999, p. 38).

44 Mennell, see note 38, p. 33.

45 Mennell, see note 38, p. 71.

46 Revel, see note 3 , ch. 5 .

47 P. Gillet, Le goût et les mots. Littérature et gastronomie (XIVe-XXe siécles), Payot, Paris, 1993, p. 101.

48 "From the eighteenth century the belief that the quality of a food depended on the predominant humor of the eater no longer held sway. And nor did the relationship between the different national cuisines and the temperament of the nation in question. These were simply considered objectively good or bad, and that was all that mattered. And even if good taste was not evenly spread among 
different nations-Voltaire discussed the matter in depth-gourmets themselves are able to appreciate good cooking wherever they happen to be. Does it not seem strange that in the seventeenth and eighteenth centuries the only good cuisines were found to be in Europe, and especially in France? No. There was no room for doubt. It became a common opinion that the French, who had learned from the Italians, had the most refined taste in the world" (J.L. Flandrin, "Dalla dietetica alla gastronomia, o la liberazione della gola," in J.-L. Flandrin and M. Montanari (eds), Storia dell'alimentazione, Laterza, Rome and Bari, 1997, p. 549).

49 See S. Peterson, Acquired Taste. The French Origins of Modern Cooking, Cornell, Ithaca and London, 1994.

50 Peterson, see note 49, p. 184.

51 Peterson, see note 49, p. 185.

52 Peterson, see note 49, p. 186.

53 Mennell, see note 38.

\section{Chapter 3 The Birth of Aesthetics and the Bifurcation of Tastes}

1 See G. Dickie, The Century of Taste. The Philosophical Odyssey of Taste in the Eighteenth Century, Oxford University Press, New York and Oxford, 1996.

2 Towards the end of the $1700 \mathrm{~s}$, Chamfort observed that "good taste and tact have more in common than many men of letters claim to believe. Tact is good taste applied to composure and conduct; and bon ton is good taste applied to discourse and conversation" (quoted in P. D'Angelo and S. Velotti (eds), Il "non so che." Storia di un'idea estetica, Aesthetica, Palermo, 1997, p. 24).

3 Voltaire, Le Mondain, 1736.

4 V. Bozal, El Gusto, Machado, Madrid, 1999.

5 W. Tatarkiewicz, A History of Six Ideas: An Essay in Aesthetics, Kluwer, Dordrecht, 1980, p. 139.

6 Tatarkiewicz, see note 5 , p. 140.

7 See B.J. Feijóo, Teatro critico universal [1765], Tomo VI, Discurso XI, EspasaCalpe, Madrid, 1944.

8 Feijóo, see note 7, p. 95.

9 Feijóo, see note 7, p. 100.

10 Feijóo, see note 7, p. 100.

11 Feijóo, see note 7, p. 101.

12 Feijóo, see note 7, p. 101.

13 E. Burke, On Taste: Introductory Discourse [1759], The Harvard Classics, Cambridge, MA, 1909-1914, p. 5.

14 Burke, see note 13, p. 6 my italics.

15 G. Sertoli, "Il gusto nell'Inghilterra del Settecento," in L. Russo (ed.), Il Gusto. Storia di un'idea estetica, cit., p. 107. 
16 Sertoli, see note 15 , p. 107.

17 Sertoli, see note 15 , p. 106.

18 P. Bourdieu, Les règles de l'art, Seuil, Paris, 1992, p. 472.

19 Sertoli, see note 15 , p. 102.

20 Sertoli, see note 15, p. 103.

21 S. Givone, "L'estetica del Novecento," in M. Ferraris, S. Givone and

F. Vercellone, Estetica, Tea, Milan, 2000, p. 85.

22 D. Hume, Of the Standard of taste [1741], The Harvard Classics, Cambridge, MA, 1909-1914, p. 7.

23 Hume, see note 22, p. 8.

24 Hume, see note 22, p. 15.

25 Hume, see note 22, p. 9.

26 Hume, see note 22, p. 16.

27 Hume, see note 22, p. 18.

28 I. Kant, Critique of the Power of Judgment, Cambridge University Press, Cambridge, 2000, pp. 215-20.

29 L. Ferry, Homo Aestheticus. The Invention of Taste in the Democratic Age, University of Chicago Press, Chicago, 1993.

30 Ferry, see note 29, p. 58.

31 Hume, see note 22, p. 26, my italics.

32 See D. Summers, "Why did Kant call taste a 'common sense'?," in P. Mattick (ed.), Eighteenth-Century Aesthetics and the Reconstruction of Art, Cambridge University Press, Cambridge, New York and Victoria, 1993, pp. 120-51.

33 R. Schusterman, "Of the scandal of taste: social privilege as nature in the aesthetic theories of Hume and Kant," in Mattick, see note 32, p. 102.

34 Schusterman, see note 33 .

35 D. Hume, "Of refinement in the arts" [1753], in D. Hume, Political Discourses, Part II, Essay II.

36 D. Hume, A Treatise of Human Nature [1739-1740], Book II, Part II, Section V.

37 D. Hume, A Treatise of Human Nature [1739-1740], Book III, Part III, Section I.

38 Ferry, see note 29, p. 74.

39 Tatarkiewicz, see note 5 , p. 312.

40 A.G. Baumgarten, Aesthetica, Olms, Hildesheim, 1970.

41 C. Batteux, Les Beaux-Arts rèduits à un même principe, Durand, Paris, 1746.

42 See J. Barnouw, “The beginnings of 'aesthetics' and the Leibnizian Conception of sensation," in Mattick, see note 33, p. 80.

43 In his Critique of Judgment, see note 28, Kant used the term "aesthetic" in the etymological sense to refer to both bodily and spiritual sensitivity (in other words, the experience of beauty that was later to become its meaning).

$44 \mathrm{~J}$. Stolnitz, "On the origins of 'aesthetic disinterestedness", Journal of Aesthetics and Art Criticism, XX (1961), pp. 131-43.

45 I. Kant, see note 28. 
46 Kant, see note 28, p. 92.

47 Kant, see note 28, p. 92.

48 Kant, see note 28, p. 93.

49 Kant, see note 28, p. 97.

50 Kant, see note 28, p. 97.

51 Kant, see note 28, p. 99.

52 Kant, see note 28, p. 106.

53 Kant, see note 28, p. 107.

54 Kant, see note 28, p. 108.

55 Kant, see note 28, p. 108.

56 Kant, see note 28, p. 94.

57 Kant, see note 28, p. 96.

58 Kant, see note 28, p. 121.

59 Kant, see note 28 , pp. 165-6.

60 Summers, note 32 .

61 Kant, see note 28, p. 163.

62 Kant, see note 28, p. 163.

63 Kant, see note 28, p. 165.

64 Kant, see note 28, pp. 170, 173.

65 Kant, see note 28, p. 176.

66 Kant, see note 28, p. 177.

67 Kant, see note 28, p. 185 (clearly borrowed from Batteux).

68 Kant, see note 28 , p. 163.

69 Kant, see note 28, p. 163.

70 Kant, see note 28, p. 182.

71 Kant, see note 28, p. 206.

72 Kant, see note 28, p. 207.

73 Kant, see note 28, p. 211.

74 Tatarkiewicz, see note 5, p. 16.

75 Tatarkiewicz, see note 5, pp. 14, 15.

76 Tatarkiewicz, see note 5 , p. 84.

77 Tatarkiewicz, see note 5 , p. 84.

78 Poetry for the Ancient Greeks was always recited, never written. Moreover, there was no form of exclusively instrumental music, because the voice always played a part in it, accompanied by poetry or dance.

79 Tatarkiewicz, see note 5, p. 111.

80 Tatarkiewicz, see note 5, p. 114.

81 H.R. Jauss, Kleine Apologie der Ästhetische Erfahrung, Universitätsverlag, Konstanz, 1972, p. 9.

82 Jauss, see note 81, p. 10. 
83 C. Korsmeyer, Making sense of Taste. Food and Philosophy, Cornell University Press, Ithaca and London, 1999, p. 51.

84 I. Kant, Anthropology From a Pragmatic Point of View [1798], Cambridge University Press, Cambridge, 2006, p. 4.

85 Kant, see note 84 .

86 Kant, see note 84 , my italics.

87 T. Eagleton, The Ideology of the Aesthetic, Oxford, Blackwell, 1990, p. 9.

88 Eagleton, see note 87, p. 23.

89 Eagleton, see note 87 , pp. 93-4.

90 "There is a difficult tension within bourgeois society between the ideology of production and the ideology of consumption. Since the former realm is generally unpleasant, sanctions and disciplines are required for the subject to buckle itself in its tasks. There is no suggestion that this world of production exists for the subject [.. . ] Like Kant's aesthetic object, the commodity would seem designed especially for our faculties, addressed to us in its very being. Viewed from the standpoint of consumption, the world is uniquely ours, shaped to nestle in our palms" (Eagleton, see note 87, p. 92).

91 Eagleton, see note 87, p. 96.

92 C. Weneger, The Discipline of Taste and Feeling, University of Chicago Press, Chicago and London, 1992, p. 28.

93 P. Bourdieu, Distinction. A Social Critique of the Judgment of Taste, Routledge, New York, 2013.

94 Bourdieu, see note 93, p. 488.

95 Bourdieu, see note 93, p. 493.

96 T. Eagleton, The Function of Criticism, Verso, London, 1984, p. 16.

97 N. Schneider, Geschichte der Ästhetik von der Aufklärung bis zur Postmoderne, Reclam, Stuttgart, 1996, p. 43.

98 Schneider, see note 97, p. 52.

99 See J.-L. Flandrin, "Distinctions through taste," in P. Ariès and G. Duby, A History of Private Life: Passions of the Renaissance, Harvard University Press, Cambridge, MA, 2003.

\section{Chapter 4 The Arts of Happiness: A Journey Through Impure Tastes}

1 J. de Berchoux, La Gastronomie ou l'homme de champe à table. Poème didactique en IV chants pour servir de suite a l'Homme des champs, Giguet et Michaud, Paris, 1801.

2 G. de la Reynière, «Itineraire nutritif ou promenade d'un gourmand dans divers quartier de Paris ", 1803, reprinted in G. de la Reynière, Ecrits gastronomiques, 10/18, Paris, 1978, p. 233. On the same subject see also J.-P. Pitte, "Nascita e diffusione dei ristoranti," in J.-L. Flandrin and M. Montanari (eds), Storia dell'alimentazione, Laterza, Rome and Bari, 1997, pp. 601-9. 
3 T. Zeldin, Histoire des passions françaises 1848-1945. 3. Gô̂t et corruption, Seuil, Paris, 1981, p. 439.

4 J.P. Aron, The Art of Eating in France: Manners and Menus in the Nineteenth Century, Harper \& Row, New York, 1975, p. 112.

5 J.-C. Bonnet, introduction to G. de La Reynière, Ecrits gastronomiques, see note 2 , p. 30.

6 J.-L. Flandrin, "Gourmets, gourmands et friands," in Croniques de Platine. Pour une gastronomie historique, Jacob, Paris, 1992, pp. $93 \mathrm{ff}$.

7 Bonnet, see note 5, p. 29.

8 P. Gillet, Soyons Français à table!, Payot, Paris, 1994, pp. 131-2.

$9 \mathrm{~J}$. de Berchoux would appear to have become the Baumgarten of the situation.

10 See G. Marchesi and L. Vercelloni, La tavola imbandita. Storia estetica della cucina, Laterza, Rome-Bari, 2001, ch. II, $\$ 1$ (Il pasticciere architetto).

11 Bonnet, see note 5, p. 24.

12 Gillet, see note 8, p. 133.

13 F. Portinari, "Introduction" to G. de La Reynière, Almanacco dei buongustai seguito dal Manuale dell'Anfitrione, Serra e Riva, Milan, 1981, p. 15.

14 Bonnet, see note 5 , p. 46.

15 R. Barthes, Physiologie du goût avec une Lecture de Roland Barthes, Hermann, Paris, 1975 , p. 8.

16 Bonnet, see note 5 , p. 51.

17 J.A. Brillat-Savarin, The Physiology of Taste, Dover, Toronto, 2002, p. 251.

18 In Meditation XII, towards the end of an original "physiognomic analysis," Brillat-Savarin claimed the existence of a social class better suited than others to the cult of good food: "Men of finance are the heroes of gourmandise." To whom he added doctors, men of letters and bigots as lesser ranking priests of the new religion.

19 P.J.G. Cabanis, Relations between the Physical and Moral Aspects of Man, Johns Hopkins University Press, Baltimore, 1981.

20 M. Faucheux, Fêtes de Table, Lebaud, Paris, 1997, p. 187.

21 The complete title of Brillat-Savarin's treatise is Physiologie du gôtt. Méditations de gastronomie trascendante.

22 M. Onfray, La raison gourmande, Paris, Grasset, 1995, p. 114.

23 C.F. Volnay, Tableau du climat et du sol del États Unis d'Amerique, CourcierDentu, Paris, 1803.

24 See S. Moravia, "Filosofia e medicina in Francia nel XVIII secolo," in S. Moravia, Filosofia e scienze umane nell'età dei Lumi, Sansoni, Florence, 1982, pp. $109 \mathrm{ff}$.

25 Meditation XXI of the Physiology of Taste, devoted to obesity, begins with a telling "If I were a trained physician" (Brillat-Savarin, see note 17, p. 172).

26 Brillat-Savarin, see note 17, Meditation XXI, p. 180.

27 Brillat-Savarin, see note 17, Meditation III, p. 33.

28 Brillat-Savarin, see note 17, Meditation XIII, pp. 126-30. 
29 Brillat-Savarin, see note 17, Aphorisms, p. 4.

30 Brillat-Savarin, see note 17, Dialogue, p. 6.

31 M. Facheaux, Fêtes de table, Lebaud, Paris, 1997, pp. 193-4.

32 Facheaux, see note 31, p. 194.

33 Brillat-Savarin, see note 17, "Footnote of a patriotic gastronome," Meditation XI, p. 113.

34 This is how Brillat-Savarin liked to refer to himself, though of course no mention is made of the related seat of Academia.

35 In other words, The Physiology of Taste (see Brillat-Savarin, see note 17).

36 Brillat-Savarin, see note 17, p. 113.

37 H. de Balzac, Traité de la vie élégante [1830], Payot \& Rivages, Paris, 2012.

38 See R. König, Macht und Reiz der Mode, Econ, Düsseldorf and Wien, 1971.

39 D. Roche, Histoire de choses banales. Naissance de la consommation (XXVIIeXIXe siècle), Fayard, Paris, 1997, p. 209.

40 The one difference lies in intensity and duration: while you can change restaurant every evening, fashion calls for devotion that lasts at least one season.

41 The period from the second half of the nineteenth century through to the early 1960 s. See G. Lipovetsky, L'empire de l'éphémère. La mode et son destin dans les sociétés modernes, Gallimard, Paris, 1987, ch. II.

42 The "Great Sacrifice" is the historical phenomenon that marked the rejection of frivolity on the part of male elegance and the adoption in its stead of dark, drab and serious middle-class attire that stood for the new ideals of work, commitment and profit. The expression was coined by John Carl Flügel in his Psychology of Clothes, The Hogarth Press, London, 1930.

43 P. Perrot, Fashioning the Bourgeoisie. A History of Clothing in the Nineteenth Century, Princeton University Press, Princeton, 1996, p. 30.

44 See P. Sparke, As Long as It's Pink. The Sexual Politics of Taste, Pandora, London and San Francisco, 1995.

45 Lipovetsky, see note 41, p. 107.

46 Lipovetsky, see note 41, p. 32.

47 "Among savage peoples, clothing and decoration (like their antecedents, tattooing, painting, etc.) start anatomically at or near the genital region, and have very frequently some definite reference to a sexual occasion (puberty, marriage, etc.)" (Flügel, see note 42, p. 26).

48 Tatarkievicz, see note 5, p. 121.

49 D. Hume, A Treatise of Human Nature, XI (1740), Oxford University Press, Oxford, 2000.

50 G. Simmel, "Die Koketterie," in Philosophische Kultur, Klinkhardt, Leipzig, 1911, p. 115.

51 Voltaire, "Goût," in Encyclopédie ou dictionnaire raisonnée des sciences, des arts et des métiers, vol. VII, Livourne, 1778, p. 746.

52 I. Kant, Anthropology from a Pragmatic Point of View [1798], Cambridge University Press, Cambridge, 2006, pp. 142-3. 
53 Kant, see note 52 .

54 Kant, see note 52, p. 148.

55 See A. Schopenhauer, Parerga and Paralipomena. A Collection of Philosophical Essays, Cosimo, New York, 2007.

56 Schopenhauer, see note 52, p. 74.

57 Schopenhauer, see note 52, p. 75.

58 W.G. Sumner, Folkways: A Study of the Sociological Importance of Usages,

Manners, Customs, Mores, and Morals, Ginn \& Co., Boston, 1906, p. 194.

59 Lipovetsky, see note 5, p. 67.

60 Lipovetsky, see note 5 , p. 68.

\section{Chapter 5 The Economy of Taste in Consumer Society}

1 É. Zola, Au Bonheur des Dames, Flammarion, Paris, 1999 (1883), p. 131.

2 Quoted by W. Benjamin in The Arcades Project, Harvard University Press, Boston, 1999 , p. 31.

3 Benjamin, see note 2, p. 42.

4 Benjamin, see note 2, p. 11.

5 M.B. Miller, The Bon Marché. Bourgeois Culture and the Department Store, 1869-1920, Princeton University Press, Princeton, 1981, p. 183.

6 Benjamin, see note 2 , p. 7.

7 O. Rühle quoted by Benjamin, see note 2, p. 181.

8 D. Harris, Cute, Quaint, Hungry and Romantic. The Aesthetic of Consumerism, Basic Books, New York, 2000, p. X.

9 R.H. Williams, Dream Worlds: Mass Consumption in Late Nineteenth-Century France, University of California Press, Berkeley and Los Angeles, 1982, p. 71.

10 P. Bourdieu, Distinction. A Social Critique of the Judgment of Taste, Routledge, New York, 2013, pp. 488-9.

11 Bourdieu, see note 10 .

12 P. Perrot, "De l'apparat au bien-être: les avatars d'un superflu nècessaire," in J.P.

Goubert (ed.), Du luxe au confort, Belin, Paris, 1988, p. 45.

13 See P. Sparke, As Long as It's Pink. The Sexual Politics of Taste, Pandora, London and San Francisco, 1995, p. 39.

14 H.P. Berlage, "Some reflections on classical architecture" (1908), in Thoughts on Style 1886-1909, The Getty Center Publication Program, Santa Monica, 1996, pp. 123-6.

15 A. Loos, Ornament and Crime (1908), Ariadne Press, Riverside, 1998, p. 167.

16 Loos, see note 15.

17 Henry Van de Velde (1863-1957) was one of the principal exponents of Art Nouveau. 
18 Loos, see note 15 , p. 155.

19 Loos, see note 15 , p. 187.

20 Loos, see note 15 , p. 185 (my italics).

$21 \mathrm{~S}$. Ewen, All Consuming Images. The Politics of Style in Contemporary Culture, Basic Books, New York, 1988, pp. 130-1.

22 It is no coincidence that some of the foremost names applied to this trend derived from specialized furniture stores: the Art Nouveau store in Paris, Liberty's in London, and-to a slightly lesser extent-Tiffany in New York. No commercial concern, however fearless in its ambition, could have volunteered to "launch" the rationalist style.

23 Le Corbusier-Saugnier, “Trois rappels à Mm. les Architectes,” in L'Esprit Nouveau, 4 January 1921, p. 457.

24 C.G. Argan, L'arte moderna, Sansoni, Florence, 1988, p. 275.

25 S. Ewen, see note 21, p. 143.

26 P. Blake, Form Follows Fiasco. Why Modern Architecture Hasn't Worked, Atlantic and Little, Brown \& Co., Boston and Toronto, 1997, p. 144.

27 Blake, see note 26, p. 138.

28 Blake, see note 26, p. 143.

29 Blake, see note 26 , p. 65.

30 O. Boissière, Streamline. Le design americain des années 30-40, Rivage, Paris and Marseille, 1987, p. 15.

31 G. Dorfles, Il Kitsch. Antologia del cattivo gusto, Mazzotta, Milan, 19764, p. 265.

32 V. Gregotti, "Kitsch e architettura," in Dorfles, see note 31, p. 267.

33 Although it was more expressive, imaginative and colorful, the Post-Modernists did not really bring about much in the way of change regarding the received taste of the Modernist Movement. In a famous pamphlet Tom Wolfe described Post-Modernism as a form of "scholasticism" invented to "test the subtlety of other architects," in other words of orthodox Modernists (see T. Wolfe, From Bauhaus to Our House, Bantam Books, New York, 1999, p. 81).

34 Blake, see note 26.

35 Le Corbusier, "Eyes which do not see .. . III: Automobiles" (1921), in Towards a New Architecture, Dover, Mineola, NY, 1985, p. 359. The conclusion is particularly interesting: the plain "English suit" is the antithesis to the fatuity of women's fashions, while the "easel paintings" of the gentleman (as opposed to the trinkets and the naïve frescoes of the peasant) establish the proper rules of aesthetic enjoyment.

36 F. Haskell, "Enemies of Modern Art," The New York Reviews of Books, June $30,1983$.

37 Haskell, see note 26.

38 W. Benjamin, The Work of Art in the Age of its Technological Reproducibility, Belknap (Harvard University Press), Boston, 2008.

39 Much the same thing had happened five years earlier with another famous work by Duchamp, the Futuristic Nude going down stairs $n .2$, which also met with 
aesthetic incomprehension, albeit of a different nature, and was rejected by the organizing committee of the Salon of Independent Artists in Paris.

40 N. Heinich, Le triple jeu de l'art contemporain, Les Èditions de Minuit, Paris, 1998, p. 31.

41 Heinich, see note 40, p. 34.

42 T. de Duve, Résonances du readymade, Chambon, Nîmes, 1989, p. 15. The snow shovel mentioned by the author refers to another famous ready-made by Duchamp.

43 In this regard I should like to turn to a personal memory. At the beginning of the 1970s I was fortunate enough to meet Man Ray, the artist-photographer who had been a friend and disciple of Marcel Duchamp. Man Ray told me that, greatly saddened by the latter's death, he had spent two whole days and nights of the funeral vigil photographing the artist's dead body. Although several years had gone by, he had still not found the courage to develop these photographs. One cannot help wondering what became of the films: what lost masterpieces ended up among the trash rather than being handed down to the voyeurism of posterity?

44 See J. Clair, Sur Marcel Duchamp et la fin de l'art, Gallimard, Paris, 2000.

45 See D. Kuspit, Idiosyncratic Identities. Artists at the End of Avant-Garde, Cambridge University Press, Cambridge, 1996.

46 T. de Duve, Kant after Duchamp, MIT Press, Cambridge, MA, 1996, p. 336.

47 O. Paz, Marcel Duchamp: l'apparence mise à nu..., Gallimard, Paris, 1977, p. 30.

48 "Taste rejects perusal and judgment, which pertain to the gourmet. It is torn between instinct and fashion, style and dictate. It expresses a skin-deep idea of art, something merely sensorial and social: a tickling and a sign of distinction. In the first case, taste reduces art to a sensation. In the second, it introduces a social hierarchy based on a reality that is as mysterious and arbitrary as purity or blood and color of skin. The phenomenon is more evident still in our own times: following Impressionism, painting becomes material, color, design, consistence, sensibility, sensuality. The ready-made is a criticism of 'retinic,' manual art" (Paz, see note 47, p. 31).

49 "The artist is not a maker; his works are not things, they are acts" (Paz, see note 47).

50 "Duchamp will have nothing to do with the idea of Beauty, and instead invents an art that is radically cerebral, conceptual and intellectual" (M. Onfray, Antimanuel de philosophie, Bréeal, Rosny, 2001, p. 80).

51 "If industrialization has effectively made craftsmanship pointless, then manual ability is something that an artist aware of his times must consider to be impossible. When manual skill, ability and talent are no more, all that remains is genius, or Witz" (de Duve, see note 42, p. 146).

52 "Beauty flushed away. What is the meaning of the revolution brought about by the urinal? Duchamp delivers a death sentence to Beauty, as others had to the idea of God (the French Revolution in History, or Nietzsche in philosophy). Following Duchamp, no one approaches art any more thinking of beauty, but rather of Meaning. A work of art no longer needs to be beautiful, but it is supposed to be meaningful" (Onfray, see note 50, p. 80). 
53 Heinich, see note 40, p. 27.

54 See F. Guerrin and P. Montebello, L'art. Une théologie moderne, L'Harmattan, Paris-Montréal, 1997.

55 Heinich, see note 40, p. 313.

56 See J. Ortega y Gasset, La deshumanización del arte, Biblioteca de la Revista de Occidente, Madrid, 1925; A. Coomaraswamy, Why Exhibit Works of Art?, Luzac, London, 1943; H. Sedlmayr, Die Revolution der modernen Kunst, Rohwolt, Hamburg, 1955.

57 See J. Clair, Considérations sur l'état des beaux-arts. Critique de la modernité, Gallimard, Paris, 1983; J.-P. Domecq, Misère de l'art. Essai sur le dernier demi-siècle de création, Calmann-Lèvy, Paris, 1999; H. Obalk, Andy Warhol n'est pas un grand artiste, Flammarion, Paris, 2001.

58 B. Altshuler, The Avant-Garde in Exhibition. New Art in the 20th Century, University of California Press, Berkeley and Los Angeles, 1998, p. 136.

59 S. Guilbaut, Comment New York vola l'idée d'art moderne. Expressionisme abstrait, liberté et guerre froide, Chambon, Nîmes, 1996, p. 8.

60 "Jackson Pollock. Is he the greatest living painter in the United States?," Life, 8 August 1949, pp. 42-5.

61 C. Greenberg, "Avant-Garde and Kitsch," Partisan Review, Fall 1939, reprinted in C. Greenberg, The Collected Essays and Criticism, 1. Perceptions and Judgments, 1939-1944, University Chicago Press, Chicago and London, 1988, pp. 5-22.

62 C. Greenberg, see note 61, p. 14.

63 As Guilbaut has rightly observed (see note 59) he failed to appreciate that because art is the object of collective contemplation in a given historical and social context, avant-garde art is also ineluctably and eminently ideological, and indeed a fortiori celebrative.

64 See C. Greenberg, Homemade Aesthetics. Observations on Art and Taste, Oxford University Press, Oxford and New York, 1999.

65 See C. Greenberg, “Towards a newer Laocoon," Partisan Review, July-August 1940, reprinted in Greenberg, see note 61, pp. 23-38.

66 See A. Danto, After the End of Art. Contemporary Art and the Pale of History, Princeton University Press, Princeton, 1997.

67 See H. Rosenberg, The Tradition of the New, Horizon Press, New York, 1959, and The De-definition of Art. Action Art from Pop to Earthworks, Horizon Press, New York, 1972.

68 Heinich, see note 40, p. 19.

69 H. Obalk, see note 57, p. 153.

70 See H. Belting, Das Ende des Kunstgeschichte, Deutscher Kunstverlag, Munich, 1983; A. Danto, "The end of art," in B. Lang (ed.), The Death of Art, Haven, New York, 1984, pp. 3-35; R.C. Morgan, The End of Art World, Allworth Press, New York, 1998.

71 See J. Baudrillard, Le complot de l'art, Sens \& Tonka, Paris, 1999.

72 See de Duve, note 42.

$73 \mathrm{~L}$. Ferry, Le sens du beau. Aux origines de la culture contemporaine, Livre de Poche, Paris, 2001, p. 16. 
74 See D. Kuspit, Psychostrategies of Avant-Garde Art, Cambridge University Press, Cambridge, 2000.

75 G. Dorfles, Le oscillazioni del gusto e l'arte moderna, Lerici, Milan, 1956, p. 52.

76 Dorfles, see note 75 , p. 53.

77 Ferry, see note 73, p. 21.

78 Ferry, see note 73, p. 27.

79 F. Monneyron, De la frivolité essentielle. Du vêtement et de la mode, Puf, Paris, 2001.

80 A fashion garment or object that carries a designer logo is thus pleonastic.

81 J. Gronow, The Sociology of Taste, Routledge, London and New York, 1997, p. 91.

82 See T. Agins, The End of Fashion. How Marketing Changed the Clothing Business Forever, Quill, New York, 2000.

83 See U. Volli, Contro la moda, Feltrinelli, Milan, 1988.

84 "My name has become more important than my person," as Pierre Cardin famously put it.

85 P. Bourdieu and Y. Delsaut, "Le couturier et sa griffe: contribution à une théorie de la magie," Actes de la Recherches en Sciences Sociales, 1: 21, January 1975.

86 Bourdieu and Delsaut, see note 85 .

87 F. Lyotard, La condition postmoderne, Les Editions de Minuit, Paris, 1979.

88 D. Lyons, Postmodernity, University of Minnesota Press, Minneapolis, 1999.

89 F. Jameson, Postmodernism, or, The Cultural Logic of Late Capitalism, Duke University Press, Durham, 1991.

90 J. Baudrillard, L'échange simbolique et la mort, Gallimard, Paris, 1976.

91 M. Featherstone, Consumer Culture and Postmodernism, Sage, London, 1990.

92 N. Klein, No Logo: Taking Aim at the Brand Bullies, Picador, New York, 1999.

93 Klein, see note 92, p. 4.

94 Klein, see note 92, p. 30.

95 See L. Vercelloni, "No logo, no global, no fun. Chi è d'accordo alzi la mano," Mark-up, 86: 78-9, November 2001.

96 See T. Polhemus, Street Style: from Sidewalk to Catwalk, Thames and Hudson, London, 1994

97 F. Davis, Fashion, Culture and Identity, University of Chicago Press, Chicago, 1992, p. 107.

98 See M. Lee, Fashion Victim. Our Love-Hate Relationship with Dressing, Shopping, and the Cost of Style, Broadway Books, New York, 2003.

99 D. Richie, The Image Factory: Fads and Fashions in Japan, Reaktion Books, London, 2003, pp. 35-8.

100 A. Gomarasca, "Occidente estremo," in A. Gomarasca and L. Valtorta, Sol mutante. Mode, Giovani e umori nel Giappone contemporaneo, Costa \& Nolan, Ancona-Milan, 1966, p. 30. 
101 Gomarasca, see note 100 , p. 39.

102 T. Miyake, "Black is beautiful. Il boom delle ganguro-gyaru," in A. Gomarasca (ed.), La bambola e il robottone. Culture pop nel Giappone contemporaneo, Einaudi, Turin, 2001, p. 141.

103 D. Waquet and M. Laporte, La mode, Puf, Paris, 1999, p. 60.

104 S. and E. Ewen, Channels of Desire. Mass Images and the Shaping of American Consciousness, Minnesota University Press, Minneapolis, 1992, p. 60.

105 A. Ehrenberg, La fatigue d'être soi. Dépression et société, Odile Jacob, Paris, 2000 .

106 Ehrenberg, see note 105, p. 14.

107 Ehrenberg, see note 105, p. 277.

108 P. Bruckner, L'euphorie perpétuelle. Essai sur le devoir de bonheur, Grasset, Paris, 2000, p. 17.

109 Bruckner, see note 108, pp. 58-9.

110 Ehrenberg, see note 105, p. 163.

111 Ehrenberg, see note 105, p. 236.

112 C. Fischler, "Gastronomie et gastro-anomie. Sagesse du corps et crise bioculturelle de l'alimentation moderne," Communications, 31: 205-6, 1979.

113 C. Lévi-Strauss, Le totémisme aujourd'hui, Puf, Paris, 1962, p. 128.

114 See L. Vercelloni, “Big Mac 3 per cento," Slow, 10: 12-15, 1998.

115 A. and M. Keys, Mangiar bene e star bene, Piccin, Padua, 1962, p. 10.

116 L. Vercelloni, “La modernità alimentare," in Storia d'Italia, Annali 13, L'alimentazione, Einaudi, Turin, 1998, p. 973.

117 Vercelloni, see note 116, p. 978.

118 Vercelloni, see note 116, pp. 978-9. For a more detailed account of the "omnivore's paradox," see C. Fischler, L'homnivore. Le goût, la cuisine et le corps, Odile Jacob, Paris, 1990.

119 E. Dolnick, "Le paradoxe Français. How do the French eat all that rich food and skip the heart disease?," Health, 1990, pp. 41-7.

120 “60 Minutes,” 17 November 1991, CBS News.

121 Within a few weeks of the broadcast, a 40 percent increase on the American market, which contributed to a positive trend that continued into the following years.

122 C. Fischler, Du Vin, Odile Jacob, Paris, 1999, p. 183.

123 Fischler, see note 122, p. 190.

124 See G. Garrier, Histoire sociale et culturelle du vin, Larousse-Bordas, Paris, 1998.

125 D. Paolini, Viaggio nei giacimenti golosi, Mondadori, Milan, 2000, p. 7.

126 Fischler, see note 122, p. 209.

127 Fischler, see note 122, pp. 210-11.

128 Fischler, see note 112, p. 201.

129 “' 'Invented tradition' is taken to mean a set of practices, normally governed by overtly or tacitly accepted rules and of a ritual or symbolic nature, which seek 
to inculcate certain values and norms of behaviour by repetition, which automatically implies continuity with the past. In fact, where possible, they attempt to establish continuity with a suitable historic past" (E. Hobsbawm, "Inventing traditions," in E. Hobsbawm and T. Ranger, The Invention of Tradition, Cambridge University Press, Cambridge, 1983, p. 1).

130 O. Assouly, Les nourritures nostalgiques, Actes Sud, Arles, 2004, pp. 41-2.

$131 \mathrm{~F}$. Revel, Un festin en paroles. Histoire littéraire de la sensibilité gastronomique de l'Antiquité à nos jours, Plon, Paris, 1995, p. 36.

132 C. Fischler, “La cuisine et l'esprit de temps: quelques tendances récentes de la sensibilité alimentaire en France," in J. Labat, H. L. Nostrand and J.-C. Seigneuret, La France en mutation depuis 1955, Newbury House, Rowley, MA, 1979, p. 203.

133 A. Chapel, La Cuisine c'est beaucoup plus que des recettes, Laffont, Paris, 1980, p. 373.

134 L. Vercelloni, "Searching for lost tastes," Slow. The International Herald of Tastes, 5 (2002): 12.

135 See G. Marchesi and L. Vercelloni, La tavola imbandita. Storia estetica della cucina, Laterza, Rome-Bari, 2001, ch. II, $\$ 1$ (Il pasticciere architetto).

136 P. Citati, “I tiranni dell'anima,” La Repubblica, 2 January 2004, p. 37.

137 W. Sombart, Luxury and Capitalism, University of Michigan Press, Michigan, 1967.

138 A. Moles, Psychologie du Kitsch. L'art du bonheur, Mame, Paris, 1971.

139 F. Nietzsche, Nachgelassene Fragmente, 1882-84, 5(1): 209.

140 G. Lipovetsky, Le bonheur paradoxal. Essai sur la société d'byperconsummation, Gallimard, Paris, 2006, p. 37.

141 Lipovetsky, see note 140, p. 306. 


\section{BIBLIOGRAPHIES}

\section{Histories and Theories of Taste}

Agamben, G., "Gusto," in Enciclopedia, vol. 6, Einaudi, Turin, 1979, pp. 1019-38. Barrère, J.-B., L'idée de goût de Pascal à Valery, Klincksieck, Paris, 1972.

Baumgarten, G., Aesthetica [1750], Olms, Hildesheim, 1970.

Becker, G.S., Accounting for Tastes, Harvard University Press, Cambridge MA and London, 1996.

Bolles, R.C., The Hedonics of Taste, Lawrence Erlbaum Associates, Hilldale, 1991. Bourdieu, P., Distinction. A Social Critique of the Judgment of Taste, Routledge,

New York, 2013.

Bozal, V., El Gusto, Machado, Madrid, 1999.

Boyer, G., Relativisme et Esthétique: Des goûts et des couleurs peut-on discuter?,

Éditions universitaires européennes, Sarrenbruck, 2014.

Brugère, F., Le goût. Art, passion et société, Puf, Paris, 2000.

Burke, E., A Philosophical Enquiry into the Origin of our Ideas of the Sublime and Beautiful, Oxford University Press, Oxford, 2008.

- On Taste: Introductory Discourse [1759], The Harvard Classics, Cambridge, MA, 1909-14.

Cornerhouse Gallery, The Ministry of Taste, Manchester, 1999.

- Taste: The New Religion, Manchester, 2000.

Cottom, D., "Taste and the civilized imagination," Journal of Aesthetics and Art Criticism, 39: 367-80, 1981.

Croce, B., Storia dell'età barocca in Italia, Laterza, Bari, 1929.

_ Filosofia. Poesia. Storia, Ricciardi, Milan and Naples, 1951.

_ Estetica come scienza dell'espressione e linguistica generale. Teoria e storia [1941], Adelphi, Milan, 1990.

D’Angelo P., and S. Velotti (eds), Il “non so che.” Storia di un'idea estetica, Aesthetica, Palermo, 1997.

De Robertis, D., “'Buon Gusto’ quattrocentesco,” Lingua Nostra, V(3): 65-7, September 1974.

Descuret, G.B.F., Théorie morale du goût, ou le goût considéré dans ses rapports avec la nature, les beaux-arts, les belles-lettres et les bonnes mours, Périsse frères, Paris and Lyon, 1847.

Dickie, G., The Century of Taste. The Philosophical Odyssey of Taste in the Eighteenth Century, Oxford University Press, New York and Oxford, 1996.

Diderot, D., Traité du Beau [1751], La Republique des Lettres, Paris, 2012.

Dumayet, P., Des goûts et des dégoûts, L'échoppe, Paris, 1996.

Ferraris, M., S. Givone and F. Vercellone, Estetica, Tea, Milan, 2000.

Feijóo, B.J., Teatro critico universal [1765], Tomo VI, Discurso XI, Espasa-Calpe, Madrid, 1944. 
Ferry, L., Homo Aestheticus. The Invention of Taste in the Democratic Age, University of Chicago Press, Chicago, 1993.

L Le sens du beau. Aux origines de la culture contemporaine, Le livre de poche, Paris, 2001.

Frackowiack, U., Der gute Geschmack. Studien zur Entwicklung des Geschmackbegriff, Fink, Monaco, 1994.

Gang, G. and P. Ariès, Le Goût, Desclée de Brouwer, Paris, 1999.

Gans, H.J., Popular Culture and High Culture. An Analysis and Evaluation of Taste, Basic Books, New York, 1999.

Gerard, A., An Essay on Taste, London, 1759.

Gracián, B., Agudeza y arte de ingenio, Nogues, Huesca, 1648.

Gronow, J., The Sociology of Taste, Routledge, London and New York, 1997.

Gruyer, P., Kant and the Claim of Taste, Cambridge University Press, Cambridge, 1997.

Knowledge, Reason, and Taste: Kant's Response to Hume, Princeton University Press, Princeton, NJ, 2008.

Hillman, J., "Politics of beauty," in City and Soul, Spring, Glasgow, 2006.

Hogarth, W., The Analysis of Beauty [1753], Clarendon Press, Oxford, 1955.

von Hoffman, V., Gô̂ter le monde: une histoire culturelle du gô̂t à l'époque moderne, Peter Lang, Pieterlen, 2013.

Howes, D. and M. Lalonde, "the history of sensibilities: of the standard of taste in eighteenth-century England and the circulation of smells in post-revolutionary France," Dialectical Anthropology, 16: 125-35, 1991.

Hume, D., A Treatise of Human Nature [1739-1740], Book II, Part II, Section V.

- Of the Standard of taste [1741], The Harvard Classics, Cambridge, MA, 1909-1914.

- Of Refinement in the Arts [1753], in D. Hume, Political Discourses, Part II, Essay II.

Hutcheson, F., An Inquiry into the Original of our Ideas of Beauty and Virtue [1726], Liberty Fund, Indianapolis 2004.

Kant, I., Critique of the Power of Judgment [1790], Cambridge University Press, Cambridge, 2000.

- Anthropology from a Pragmatic Point of View [1798], Cambridge University Press, Cambridge, 2006.

Klein, R., Form and Meaning: Essays on the Renaissance and Modern Art [1970], Princeton University Press, Princeton, 1980.

Korsmeyer, C., "Taste as sense and sensibility," Philosophical Topics, 25(1): 201-30, 1997.

— Making Sense of Taste. Food and Philosophy, Cornell University Press, Ithaca and London, 1999.

Levine, L.W., Highbrow Lowbrow. The Emergence of Cultural Hierarchy in America, Harvard University Press, Cambridge, MA and London, 1998.

Lynes, R., The Taste Makers, Harper and Bros, New York, 1955.

McCracken, J., Taste and the Household. The Domestic Aesthetic and Moral Reasoning, State University of New York Press, Albany, 2001.

Macdonald, D., "Masscult e midcult," Partisan review, 27: 203-33, 1960.

Miller, W.I., The Anatomy of Disgust, Harvard University Press, Cambridge, MA, and London, 1997.

Montesquieu, Essai sur le goût [1757], Gallimard, Paris, 2010.

Muratori, L., Riflessioni sopra il buon gusto nelle scienze e nelle arti, Venice, 1723. 
Pietra R. (ed.), Esthétique: des goûts et des couleurs ..., Recherches sur la philosophie et le langage, Grenoble, 1998.

Rosenkranz, K., Ästhetik der Häßlichen [1853], Reclam, Dizingen, 2007.

Russo L. (ed.), Il Gusto. Storia di un'idea estetica, Aesthetica, Palermo, 2000.

Schümmer, F., "Die Entwicklung des Geschmackbegriff in der Philosophie des 17. und 18. Jahrhunderts," Archiv für Begriffsgaschichte, 1: 120-41, 1956.

Sparke, P., As Long as It's Pink. The Sexual Politics of Taste, Pandora, London and San Francisco, 1995.

Strube, V.W., "Zur Geschichte des Sprichworts, Über den Geschmack läßt sich nicht streiten'," Zeitschrift für Ästhetik und Allgemeine Kunst-Wissenschaft, XXX(1): 158-85, 1985.

Tacitus, Annals, XVI.

Thomas Aquinas in Quaestiones disputatae De malo.

Vercelloni, L., "La dichotomie chez Kant et le destin de l'agréable," in O. Assouly (ed.), Goûts à vendre : Essais sur la captation esthétique, IFM, Paris, 2008 pp. 75-91.

Veronese, P., Ipotesi per una filosofia del "gusto," Marsilio, Venice, 1972.

Voltaire, "Goût," in Encyclopédie ou dictionnaire raisonnée des sciences, des arts et des métiers, tomo VII, Livourne, 1778, pp. 746-7.

Weneger, C., The Discipline of Taste and Feeling, University of Chicago Press, Chicago and London, 1992.

\section{Histories of Customs, Morals, Mindsets and Sensibilities}

d'Aquino, T., Quaestiones disputatae De malo, 1269.

- Summa theologiae, 1259-1273.

de Balzac, H., Traité de la vie élégante [1830], Payot \& Rivages, Paris, 2012.

Baudrillard, J., L'échange simbolique et la mort, Gallimard, Paris, 1976.

Berg, M. and H. Clifford (eds), Consumers and luxury. Consumer culture in Europe 1650-1850, Manchester University Press, Manchester and New York, 1999.

Berry, C.J., The Idea of Luxury. A Conceptual and Historical Investigation, Cambridge University Press, Cambridge, 1994.

Borghero, C. (ed.), La polemica sul lusso nel Settecento francese, Einaudi, Turin, 1974.

Braudel, F., Civilisation matérielle, économie et capitalisme. XVe au XVIIIe siècle 2. Les jeux de l'échange, Colin, Paris, 1979.

Bruckner, P., L'euphorie perpétuelle. Essai sur le devoir de bonheur, Grasset, Paris, 2000.

Cabanis, P.J.G., Rapports du physique et du moral de l'homme, Paris, 1796-1808.

Campbell, C., The Romantic Ethic and the Spirit of Modern Consumerism, Blackwell, Oxford, 1981.

Canévet, M., P. Adnès, W. Yeomans and A. Derville, Les sens spirituels, Beauchesne, Paris, 1993.

Casagrande, C. and S. Vecchio, I sette peccati capitali. Storia dei peccati nel Medioevo, Einaudi, Turin, 2000.

De Jean, J., The Essence of Style. How the French Invented High Fashion, Fine Food, Chic Cafés, Style, Sophistication, and Glamour, Free Press, New York, 2005. 
Delon, M., Le savoir-vivre libertin, Hachette, Paris, 2000.

Ehrenberg, A., La fatigue d'être soi. Dépression et société, Jacob, Paris, 2000.

Elias, N., The Court Society [1965], University College Dublin Press,

Dublin, 2006;.

- The Civilizing Process [1969], Blackwell, Oxford, 2000.

Galimberti, U., I vizi capitali e i nuovi vizi, Feltrinelli, Milan, 2003.

Géné J.P. and M. Ndiaye, La Gourmandise. Les Péchées capitaux., Éditions du

Centre Pompidou, Paris, 1996.

Goubert J.P. (ed.), Du luxe au confort, Belin, Paris, 1988.

Jameson, F., Postmodernism, or, The Cultural Logic of Late Capitalism, Duke

University Press, Durham, 1991.

Laurent, A., De l'individualisme, enquête sur le retour de l'individu, Presses

Universitaires de France, Paris, 1985.

Lyons, D., Postmodernity, University of Minnesota Press, Minneapolis, 1999.

Lyotard, F., La condition postmoderne, Les Éditions de Minuit, Paris, 1979.

The Postmodern Explained: Correspondence, 1982-1985, University of

Minnesota Press, Minneapolis 1993.

de Mandeville, B., The Fable of the Bees: or, Private Vices, Public Benefits [1723], Penguin, New York, 1989.

Marwick, A., Beauty in History: Society, Politics and Personal Appearance c. 1500 to the Present, Thames and Hudson, London, 1988.

Muchembled, R., L'invention de l'homme moderne. Culture et sensibilités en

France du XVe au XVIIIe siècle, Fayard, Paris, 1988.

Perrot, P., Le Luxe. Une richesse entre faste et confort. XVIIIe-XIXe siècles, Du Seuil, Paris, 1995.

Robert, J.-N., Les plaisir à Rome, Les belles lettres, Paris, 1983.

Schimmel, S., The Seven Deadly Sins. Jewish, Christian, and Classical Reflections

on Human Psychology, Oxford University Press, Oxford and New York, 1997.

Scruton, R., Modern Culture, Continuum, London, $2000^{2}$.

Solomon R.C. (ed.), Wicked Pleasures. Meditations on the Seven "Deadly" Sins,

Rowman \& Littlefield, Lanham, 1999.

Sombart, W., Luxury and Capitalism, University of Michigan Press,

Michigan, 1967.

— The Quintessence of Capitalism, Routledge, London, 1930.

— Der Bourgeois. Zur Geistesgeschichte des modernen Wirtschaftsmenschen, Duncker \& Humblot, Berlin, 1913.

Sumner, W.G., Folkways: A Study of the Sociological Importance of Usages,

Manners, Customs, Mores, and Morals, Ginn \& Co., Boston, 1906.

Tseëlon, E., The Masque of Femininity. The Presentation of Woman in Everyday

Life, Sage, London, 1995.

Verdon, J., Le Plaisir au Moyen-âge, Tempus, Paris, 2010.

Viatte, G., D. Ottinger and M. Onfray, Les Péchées capitaux., Éditions du Centre Pompidou, Paris, 1996.

Weber, C.W., Panem et circenses. Massenunterhaltung als Politik im antiken Rom, Econ, Düsseldorf/Wien, 1983.

Welch, E., Shopping in the Renaissance. Consumer Cultures in Italy 1400-1600, Yale University Press, New Haven and London, 2005.

Zeldin, T., Histoire des passions françaises 1848-1945. 3. Gô̂t et corruption,

Seuil, Paris, 1981.

_Les françaises et l'histoire intime de l'humanite, Fayard, Paris, 1994. 


\section{Art Criticism and History}

Altshuler, B., The Avant-Garde in Exhibition. New Art in the Twentieth Century, University of California Press, Berkeley and Los Angeles, 1998.

Batteaux, C., Les beaux arts reduits à un même princip, Durand, Paris, 1746.

Baudrillard, J., Le complot de l'art, Sens \& Tonka, Paris, 1999.

Belting, H., Das Ende des Kunstgeschicthe?, Deutscher Kunstverlag,

Monaco, 1983.

—Das Bild und sein Publikum im Mittelalter: Form und Funktion früher

Bildtaf. der Passion, Mann Verlag, Berlin, 1981.

Benhamou-Huet, J., Art Business. Le marché de l'art ou l'art de marchè, Assouline, Paris, 2001.

Benjamin, W., The Work of Art in the Age of its Technological Reproducibility

[1955], Harvard University Press, Boston, 2008.

Bourdieu, P., Le règles de l'art. Genèse et structure du champ littéraire, Seuil, Paris, 1992.

Broch, H., "Der Kitsch,” in Dichten und Erkennen, Bd. 1, Rhein-Verlag, Zürich 1955.

Chambers, F.P., The History of Taste. An Account of the Revolutions of Art

Criticism and Theory in Europe, Columbia University Press, New York, 1932.

Changeux, J.-P., Raison et Plaisir, Jacob, Paris, 1994.

Clair, J., Considérations sur l'état des beaux-arts. Critique de la modernité,

Gallimard, Paris, 1983.

— Sur Marcel Duchamp et la fin de l'art, Gallimard, Paris, 2000.

- De Immundo, Galilée, Paris, 2004.

Coomaraswamy, A.K., 1: Selected Papers. Traditional Art and Symbolism [1943],

Bollingen, Dehli, 1977.

Christian and Oriental Philosophy of Art, Dover Publications, New York, 1956.

"A figure of speech or a figure of thought?," in Selected Papers. Traditional Art

and Symbolism, Bollingen, Dehli, 1977.

"Ornament," in Selected Papers. Traditional Art and Symbolism, Bollingen,

Dehli, 1977.

- Why Exhibit Works of Art?, Luzac, London, 1943.

Crow, T., Modern Art in Common Culture, Yale University Press, New Haven and London, 1996.

Danto, A., The Transfiguration of the Commonplace. A Philosophy of Art,

Harvard University Press, Cambridge, MA, 1981.

- After the End of Art. Contemporary Art and the Pale of History, Princeton

University Press, Princeton, 1997.

Della Volpe, G., Storia del gusto, Editori Riuniti, Rome, 1971.

de Duve, T., Résonances du readymade. Duchamp entre avant-garde et tradition,

Chambon, Nîmes, 1989.

- Kant after Duchamp, MIT Press, Cambridge, MA, 1996.

Dickie, G., Art and Value, Blackwell, Malden and Oxford, 2001.

Domecq, J.-P., Misère de l'art. Essai sur le dernier demi-siècle de création,

Calmann-Lèvy, Paris, 1999.

Dorfles, G., Le oscillazioni del gusto e l'arte moderna, Lerici, Milan, 1956.

_ and J. McHale (eds), Kitsch: The World of Bad Taste, Bell Publishing,

New York, 1969. 
- Ultime tendenze nell'arte d'oggi, Feltrinelli, $1999^{16}$.

Eagleton, T., The Function of Criticism, Verso, London, 1984.

The Ideology of the Aesthetic, Blackwell, Oxford, 1990.

Eco, U., History of Beauty, Rizzoli, Milan, 2010.

Ferniot, J., Le gout, la sentè et l'argent, Sand, Paris, 1999.

Gilbert-Rolfe, J., Beauty and the Contemporary Sublime, Allworth Press,

New York, 1999.

Gimpel, J., Against Art and Artists [1968], Polygon, Edinburgh, 1991.

Greenberg, C., The Collected Essays and Criticism, 1. Perceptions and Judgments, 1939-1944, University of Chicago Press, Chicago and London, 1988.

- Homemade Aesthetics. Observations on Art and Taste, Oxford University

Press, Oxford and New York, 1999.

Groys, B., Du Nouveau. Essai d'économie culturelle, Chambon, Nîmes, 1995.

Guerrin, F. and P. Montebello, L'art. Une théologie moderne, L'Harmattan, Paris and Montréal, 1997.

Guilbaut, S., Comment New York vola l'idée d'art moderne. Expressionisme abstrait, liberté et guerre froide, Chambon, Nîmes, 1996.

Hauser, A., The Social History of Art [1955], Routledge, London, 1999.

Haskell, F., "Enemies of modern art," The New York Reviews of Books, 30, 1983.

Heinich, N., L'art contemporain exposé aux rejets, Chambon, Nîmes, 1997.

— Le triple jeu de l'art contemporain, Les Ėditions de Minuit, Paris, 1998.

- Pour en finir avec la querelle de l'art contemporain, L'Echoppe, Paris, 1999.

Hobsbawm, E.J., Behind the Times: The Decline and Fall of the Twentieth-Century Avant-Gardes, Thames and Hudson, London, 1998.

Hopkins, D., After Modern Art. 1945-2000, Oxford University Press, Oxford, 2000.

Jauss, H.R., Kleine Apologie der Ästhetische Erfahrung, Universitätsverlag, Konstanz, 1972.

Kuspit, D., Idiosyncratic Identities. Artists at the End of Avant-Garde, Cambridge University Press, Cambridge, 1996.

- Psychostrategies of Avant-Garde Art, Cambridge University Press, Cambridge, 2000.

Lang B. (ed.), The Death of Art, Haven, New York, 1984.

McEvilley, T., Art and Discontent. Theory at the Millennium, McPherson, New York, 1991.

Mattick P. (ed.), Eighteenth-Century Aesthetics and the Reconstruction of Art, Cambridge University Press, Cambridge, New York and Victoria, 1993.

Messadié, G., La messe de Saint Picasso, Laffont, Paris, 1989.

Michaud, Y., Critères esthétiques et jugement du goût, Chambon, Nîmes, 1999.

Morgan, R.C., The End of Art World, Allworth Press, New York, 1998.

Obalk, H., Andy Warbol n'est pas un grand artiste, Flammarion, Paris, 2001.

Onfray, M., Antimanuel de philosophie, Bréal, Rosny, 2001.

Ortega, J. and Gasset, La deshumanización del arte, Biblioteca de la Revista de Occidente, Madrid, 1925.

Paz, O., Marcel Duchamp: l'apparence mise à nu ..., Gallimard, Paris, 1977.

Perniola, M., L'estetica del Novecento, Il Mulino, Bologne, 1997.

- Disgusti. Le nuove tendenze estetiche, Costa \& Nolan, Genoa and

Milan, 1998.

Rosenberg, H., The Tradition of the New, Horizon Press, New York, 1959. The De-definition of Art. Action Art from Pop to Earthworks, Horizon Press, New York, 1972. 
Schneider, N., Geschichte der Ästhetik von der Aufklärung bis zur Postmoderne, Reclam, Stuttgart, 1996.

Sedlmayr, H., Die Revolution der modernen Kunst, Rohwolt, Hamburg, 1955.

— Verlust der Mitte. Die bildende Kunst des 19. und 20. Jahrhunderts als Symptom und Symbol der Zeit, Otto Müller Verlag, Salzburg and Wien, 1948.

Schopenhauer, A., Parerga and Paralipomena. A Collection of Philosophical Essays, Cosimo, New York, 2007.

Sollers, P., La guerre du Goût, Gallimard, Paris, 1996.

Stolnitz, J., "On the origins of 'aesthetic disinterestedness'," Journal of Aesthetics and Art Criticism, XX, 131-44, 1961.

Talon-Hugon, C., Goût et degoût. L'art peut-il tout montrer?, Chambon, Nîmes, 2003.

Tatarkiewicz, W., A History of Six Ideas: An Essay in Aesthetics [1976], Kluwer, Dordrecht, 1980.

Ward, P., Kitsch in Sync. A consumer's Guide to Bad Taste, Plexus, London, 1991.

Wolfe, T., The Painted Word [1975], Bantam Books, New York, 1999.

\section{Architecture and Design}

Bel Geddes, N., Horizons [1932], Dover, New York, 1977.

Berlage, H.P., "Some reflections on classical architecture" [1908], in Thoughts on

Style 1886-1909, The Getty Center Publication Program, Santa Monica, 1996.

Blake, P., Form Follows Fiasco. Why Modern Architecture Hasn't Worked [1974],

Atlantic and Little, Brown \& Co., Boston and Toronto, 1997.

Boissière, O., Streamline. Le design americain des années 30-40, Rivage, Paris and

Marseille, 1987.

Hitchcock, H.R. and P. Johnson, The International Style [1932], Norton,

New York, 1966.

Hoffenberg, A. and A. Lapidus, La société du design, Puf, Paris, 1977.

Jenks, C., The Prince, the Architects and New Wave Monarchy, Academy Editions, London, 1988.

Le Corbusier, "Eyes which do not see . . III: Automobiles" [1921], in Towards a

New Architecture, Dover, Mineola, NY, 1985.

— and J. Saugnier, "Trois rappels à Mm. les Architects" [1920], in Towards a

New Architecture, Dover, Mineola, NY, 1985.

Loos, A., Ornament and Crime [1908], Ariadne Press, Riverside, 1998.

Pevsner, N., The Sources of Modern Architecture and Design, Thames and Hudson, London, 1968.

- Pioneers of Modern Design [1943], Palazzo, Bath, 2011.

H.R.H. The Prince of Wales, A Vision of Britain. A Personal View of Architecture,

Doubleday, London, 1989.

Ryan, D.S., The Ideal Home through the Twentieth Century, Hazar, London, 1977.

Wolfe, T., From Bauhaus to Our House [1981], Bantam Books, New York, 1999.

\section{Food, Gastronomy and Wine}

Aron, J.P., The Art of Eating in France: Manners and Menus in the Nineteenth

Century, Harper \& Row, New York, 1975. 
Assouly, O., Les nourritures nostalgiques, Actes Sud, Arles, 2004.

_L Le capitalisme esthétique: Essai sur l'industrialisation du gô̂t, Cerf, Paris, 2008.

- (ed.), Gô̂ts à vendre : Essais sur la captation esthétique, IFM, Paris, 2008.

Bancquart, M.-C., Fin de siècle gourmande. 1880-1900, Puf, Paris, 2001.

Barthes, R., Physiologie du goût avec une Lecture de Roland Barthes, Hermann, Paris, 1975.

Beardsworth, A. and T. Keil, Sociology on the Menu. An Invitation to the Study of Food and Society, Routledge, London and New York, 1997.

Beaugé, B., Aventures de la cuisine française. Cinquante ans d'histoire du goût, Nil, Paris, 1999.

— and S. Demorand, Les cuisines de la critique gastronomique, Seuil, Paris, 2009.

Belasco, W.J. and P. Scranton (eds), Food Nations: Selling Taste in Consumer Societies, Routledge, New York, 2001.

Bell, D. and G. Valentine, Consuming Geographies. We Are Where We Eat, Routledge, London and New York, 1997.

de Berchoux, J., La Gastronomie ou l'homme de champe à table. Poème didactique en IV chants pour servir de suite a l'Homme des champs, Giguet and Michaud, Paris, 1801.

Brillat Savarin, A., Physiologie du goût. Méditations de gastronomie trascendante, Paris, 1826.

Bonnet, J.C., "Introduzione a Grimod de La Reynière," Écrits gastronomiques, 10(18): 7-92, 1978.

Boudan, C., Géopolitique du gô̂t. La guerre culinaire, Puf, Paris, 2004.

Burnham, D. and O.M. Skilleas, The Aesthetics of Wine, Blackwell, Oxford, 2012.

Capatti, A., Le goût du nouveau. Origines de la modernité alimentaire, Albin Michel, Paris, 1999.

- and M. Montanari, Italian Cuisine. A Cultural History, Columbia University Press, New York, 2003.

Courbeau, J.P. and J.P. Poulain, Penser l'alimentation. Entre imaginaire et rationalité, Privat, Toulouse, 2002.

Counihan, C., The Anthropology of Food and Body: Gender, Meaning and Power, Routledge, New York, 1999.

Davidson, J., Courtesans and Fishcakes. The Consuming Passions of Classical Athens, Fortuna Press, London, 1998.

Dermorand, N., L. Dubanchet and J.P. Géné, "La bataille du gout," GaultMillau, 339: 20-34, 2000.

Dolnick, E., "Le paradoxe Français. How do the French eat all that rich food and skip the heartdisease?," In Health, 3/4, 41-7, 1990.

"Beyond the French paradox," Health, 6/6, 40-9, 1992.

Douglas, M., "Food as an art form" [1982], in In the Active Voice, Routledge, London and New York, 2012.

Faucheux, M., Fêtes de table, Lebaud, Paris, 1997.

Fischler, C., "La cuisine et l'esprit de temps: quelques tendances récentes de la sensibilité alimentaire en France," in J. Labat, H.L. Nostrand and J.-C. Seigneuret, La France en mutations depuis 1955, Newbury House, Rowley, MA, 1979, pp. 191-207.

"Gastronomie et gastro-anomie. Sagesse du corps et crise bioculturelle de l'alimentation modern," Communications, 31: 189-208, 1979. 
L_homnivore. Le gô̂t, la cuisine et le corps, Odile Jacob, Paris, 1990.

- (ed.), Manger magique. Aliments sorciers, croyance comestibles, Autrement, Paris, 1994.

— Du Vin, Odile Jacob, Paris, 1999.

Flammang, J.A., The Taste for Civilization: Food, Politics, and Civil Society,

University of Illinois Press, Champaign, 2009.

Flandrin, J.L., Croniques de Platine. Pour une gastronomie historique, Jacob, Paris, 1992.

- "Distinctions through taste," in P. Ariès and G. Duby (eds), A History of

Private Life: Passions of the Renaissance, Vol. 3, Harvard University Press, Cambridge, MA, 2003.

- and M. Montanari (eds), Storia dell'alimentazione, Laterza, Rome and Bari, 1997.

Garrier, G., Histoire sociale et culturelle di vin, Larousse-Bordas, Paris.

Gault, H. and C. Millau, Gault et Millau se mettent à table, Stock, Paris, 1975.

Gautier, J.-F., Le vin de la mythologie à l'oenologie. L'esprit d'une civilisation,

Féret, Bordeaux, 2003.

Giachetti, I. (ed.), Plaisir et préferences alimentaires, Polytechnica, Paris, 1992.

_ Identités des mangeurs, images des aliments, Polytechnica, Paris, 1996.

Gillet, P., Le goût et les mots. Littérature et gastronomie (XIVe-XXe siècles), Payot, Paris, 1993.

- Soyons Français à table!, Payot, Paris, 1994.

Grimod de La Reynière, Écrits gastronomiques [1804-1808], 10/18, Paris, 1978.

Guy, C., La vie quotidienne de la société gourmande en France au XIXe siècle, Hachette, Paris, 1971.

Jeanneret, M., Des mets e des mots. Banquets et propos de table à la Renaissance, Librairie José Corti, Paris, 1987.

Ketcham Wheaton, B., L'office et la bouche, Historie des moeurs de la table en France 1300-1789 [1983], Calman-Lévy, Paris, 1984.

Lahlou, S., Penser manger. Alimentations et représentations sociales, Puf, Paris, 1998.

Lane, C., The Cultivation of Taste: Chefs and the Organization of Fine Dining, Oxford University Press, Oxford, 2014.

Lévi-Strauss, C., Le totémisme aujourd'hui, Puf, Paris, 1962.

Lile, P.C., Histoire médicale du vin, Oenoplurimedia, Chaintré, 2002.

Macbeth, H. (ed.), Food Preference and Taste. Continuity and Change, Berghahn Books, Providence and Oxford, 1997.

Mennell, S., All Manners of Food. Eating and taste in England and France from Middle Ages to the Present, University of Illinois Press, Urbana and Chicago, $1996^{2}$.

Morton, T. (ed.), Cultures of Taste/Theories of Appetites. Eating Romanticism, Palgrave Macmillan, New York, 2004.

N'Diaye, C., La gourmandise. Délices d'un péché, Autrement, Paris, 1993.

Onfray, M., La raison gourmande, Grasset, Paris, 1995.

Ory, P., Les discours gastronomique français des origins à nos jours, GallimardJulliard, Paris, 1998.

Paolini, D., Viaggio nei giacimenti golosi, Mondadori, Milan, 2000. Il mestiere del gastronauta, Sperling \& Kupfer, Milan, 2005.

Petrini, C., Slow Food: The Case for Taste, Columbia University Press,

New York, 2004. 
— and G. Padovani, Slow Food Revolution, Rizzoli, Milan, 2005.

Perdue, L., The French Paradox and Beyond. Live Longer with Wine and the Mediterranean Lifestyle, Renaissance Publishing, Sonoma, 1992.

Peterson, S., Acquired Taste. The French Origins of Modern Cooking, Cornell, Ithaca and London, 1994.

Pfirsch, J.-V., Le saveur des sociétés, Presses Universitaires de Rennes, Rennes, 1997.

Piault, F. (ed.), Le mangeur. Menus, mots et maux, Autrement, Paris, 1993.

Pinkard, S., A Revolution in Taste: The Rise of French Cuisine, 1650-1800, Cambridge University Press, New York, 2010.

Pitte, J.-P., Gastronomie française. Histoire et géographie d'une passion, Fayard, Paris, 1991.

Portinari, F., Introduzione a Grimod de La Reynière, Almanacco dei Buongustai seguito dal Manuale dell'Anfitrione, Serra e Riva, Milan, 1981, pp. 11-16.

Poulain, J.-P., Sociologies de l'alimentations. Les mangeurs et l'espace social alimentaire, Puf, Paris, 2002.

Revel, F., Un festin en paroles. Histoire littéraire de la sensibilité gastronomique de l'Antiquité à nos jours, Plon, Paris, 1995.

Safran, S., L'amour gourmand. Libertinage gastronomique au XVIIIe siècle, La Musardine, Paris, 2000.

Schivelbusch, W., Storia dei generi voluttuari [1980], Bruno Mondadori, Milan, 1999.

Spang, R., The Invention of the Restaurant. Paris and Modern Gastronomic Culture, Harvard University Press, Cambridge, MA, 2001.

Strong, J., Educated Tastes: Food, Drink, and Connoisseur Culture, University of Nebraska Press, Lincoln, 2011.

Telfer, E., Food for Thought. Philosophy and Food, Routledge, London and New York, 1996.

Vercelloni, L., "La modernità alimentare," in Storia d'Italia, Annali 13, L'alimentazione, Einaudi, Turin, 1998, pp. 949-1005.

- and G. Marchesi, La tavola imbandita. Storia estetica della cucina, Laterza, Rome, 2001.

— "Searching for lost tastes," Slow. The International Herald of Tastes, 5: 6-15, 2002.

"A branch of fashion," Slow. The International Herald of Tastes, 46:

82-5, 2004.

—_L'esthétisation de l'appétit ou le développement de la cuisine par la mode," Mode de recherche, 13: 1214, 2010.

- Il nuovo esperanto culinario inquina le radici del gusto, www.gastronauta.it, August 2014.

Contro gli Chef, www.gastronauta.it, August 2014.

Visser, M., The Rituals of Dinner. The Origins, Evolutions, Eccentricities, and Meaning of Table Manners, Penguin, New York, 1991.

Warde, A., Consumption, Food and Taste. Culinary Antinomies and Commodity Culture, Sage, London, 1997.

Wood, R.C., The Sociology of Meal, Edinburgh University Press, Edinburgh, 1995. 


\section{Consumption and Fashion}

Agins, T., The End of Fashion. How Marketing Changed the Clothing Business Forever, Quill, New York, 2000.

Appadurai, A. (ed.), The Social Life of Things. Commodities in Cultural

Perspective, Cambridge University Press, Cambridge, 1986.

Bauman, Z., Consuming Life, Polity Press, Cambridge, 2007.

Bell, D. and J. Hollows (eds), Ordinary Lifestyles. Popular Media, Consumption and Taste, Open University Press, New York, 2005.

Bell, Q., On Human Finery, The Hogarth Press, London, 1976.

Ben Ytzhak, L., Petite histoire du maquillage, Stock, Paris, 2000.

Benjamin, W., The Arcades Project, Harvard University Press, Boston, 1999.

Bourdieu, P. and Y. Delsaut, "Le couturier et sa griffe: contribution à une théorie de la mgie," Actes de la Recherches en Sciences Sociales, 1: 7-36, 1975.

Corrigan, P., The Sociology of Consumption, Sage, London, 1997.

Csikszentmihalyi, M. and E. Rochber-Halton, The Meaning of Things. Domestic Symbols and the Self, Cambridge University Press, Cambridge, 1981.

Davis, F., Fashion, Culture and Identity, University of Chicago Press, Chicago, 1992.

De Grazia, V., Irresistibile Empire. America's Advantage through TwentiethCentury Europe, Belknap Press, Cambridge, MA, 2006.

DeJean, J., The Essence of Style. How the French Invented High Fashion, Fine Food, Chic Cafés, Style, Sophistication, and Glamour, Free Press, New York, 2005.

Dorfles, G., Mode \& Modi, Mazzotta, Milan, 1990.

— La moda della moda, Costa \& Nolan, Milan, 1993.

Douglas, M., Thought Styles, Thousand Oaks, London and New Dehli, 1996.

Ewen, S., All Consuming Images. The Politics of Style in Contemporary Culture, Basic Books, New York, 1988.

- and E. Ewen, Channels of Desire. Mass Images and the Shaping of American Consciousness, Minnesota University Press, Minneapolis, $2000^{2}$.

Falk, P., The Consuming Body, Sage, London 1994.

Featherstone, M., Consumer Culture and Postmodernism, Sage, London, 1990.

Flügel, J.C., Psychology of Clothes, Hogarth Press, London, 1930.

Forty, A., Objects of Desire. Design and Society from Wengwood to IBM, Pantheon Books, New York, 1986.

Gans, H.J., Popular Culture and High Culture: An Analysis and Evaluation of Taste, Basic Books, New York, 1999.

Gomarasca, A. (ed.), La bambola e il robottone. Culture pop nel Giappone contemporaneo, Einaudi, Turin, 2001.

- and L. Valtorta, Sol mutante. Mode, Giovani e umori nel Giappone contemporaneo, Costa \& Nolan, Ancona and Milan, 1966.

Harris, D., Cute, Quaint, Hungry and Romantic. The Aesthetic of Consumerism, Basic Books, New York, 2000.

Haug, W.F., Critique of Commodity Aesthetics. Appearance, Sexuality and Advertising in Capitalist Society [1971], University of Minnesota Press, Minneapolis, 1986.

Hebdige, D., Hiding in the Light. On Images and Things, Routledge, London and New York, 1988.

Hine, T., I Want That! How We All Became Shoppers, HarperCollins, New York, 2002. 
Kammen, M.G., American Culture, American Tastes: Social Change and the

Twentieth Century, Basic Books, New York, 2000.

Klein, N., No Logo: Taking Aim at the Brand Bullies, Picador, New York, 1999.

König, R., Macht und Reiz der Mode, Econ, Düsseldorf and Wien, 1971.

- Menschheit auf dem Laufsteg. Die Mode im Zivilisationsprozeß, Carl Hanser

Verlag, München, 1985.

Lafosse Dauvergne, G., Mode \& Fétichisme, Éditions Alternatives, Paris, 2002.

Lanneglongue, M.-P., La mode racontée à ceux qui la portent, Hachette, Paris, 2004.

Laver, J., Costume \& Fashion, Thames and Hudson, London, 1996.

Lemoine-Luccioni, E., Psicoanalisi della moda [1982], Bruno Mondadori, Milan, 2002.

Lee, M., Fashion Victim. Our Love-Hate Relationship with Dressing, Shopping, and the Cost of Style, Broadway Books, New York, 2003.

Lipovetsky, G., L'empire de l'éphémère. La mode et son destin dans les sociétés modernes, Gallimard, Paris, 1987.

Lurie, A., The Language of Clothes, Owl Book, New York, 2000.

Mendes, V. and A. de la Haye, La mode au XXe siècle, Thames and Hudson, London, 2000.

Miller, M.B., The Bon Marché. Bourgeois Culture and the Department Store, 1869-1920, Princeton University Press, Princeton, 1981.

Miles, S., Consumerism as a Way of Life, Sage, London, 1998.

Monneyron, F., De la frivolité essentielle. Du vêtement et de la mode, Puf, Paris, 2001.

Morton, P., Pop Culture and Postwar American Taste, Blackwell, Oxford, 2008.

Obalk, H., A. Soral and A. Pasche, Le mouvements de mode expliqués aux parents, Laffont, Paris, 1984.

Perrot, P., Fashioning the Bourgeoisie. A History of Clothing in the Nineteenth Century [1981], Princeton University Press, Princeton, 1996.

_ “De l'apparat au bien-être: les avatars d'un superflu necessaire," in J.P. Goubert (ed.), Du luxe au confort, Belin, Paris, 1988.

Polhemus, T., Street Style: From Sidewalk to Catwalk, Thames and Hudson, London, 1994.

- Style Surfing. What to wear in the 3rd Millennium, Thames and Hudson, London, 1996.

Postrell, V., The Substance of Style. How the Rise of Aesthetic Value is Remaking Commerce, Culture, and Consciousness, HarperCollins, New York, 2003.

Richie, D., The Image Factory: Fads and Fashions in Japan, Reaktion Books, London, 2003.

Ritzer, G., Enchanting a Disenchanted World: Revolutionizing the Means of Consumption, Thousand Oaks, London and New Dehli, 1999.

Roche, D., La culture des apparences. Essai sur l'Histoire du vêtement aux XVIIe et XVIIIe siècles, Fayard, Paris, 1989.

- Histoire des choses banales. Naissance de la consommation (XXVIIe-XIXe siècle), Fayard, Paris, 1997.

Seabrook, J., Nobrow, Vintage Books, New York, 2000.

Simmel, G., "Die Koketterie," in Philosophische Kultur, Klinkhardt, Leipzig, 1911.

Stewart, S., A Sociology of Culture, Taste and Value, Palgrave Macmillan, London, 2013. 
Tomlinson, A., Consumption, Identity and Style. Marketing, Meanings, and the Packaging of Pleasure, Routledge, London and New York, 1990.

Trifonas, P. and E. Balomenos, Good Taste. How What You Choose Defines Who You Are, Icon Books, London, 2003.

Vercelloni, L., "No logo, no global, no fun. Chi è d'accordo alzi la mano," Mark-up, 86: 78-9, 2001.

Volli, U., Contro la moda, Feltrinelli, Milan, 1988.

Waquet, D. and M. Laporte, La mode, Puf, Paris, 1999.

Williams, R.H., Dream Worlds: Mass Consumption in Late Nineteenth-Century

France, University of California Press, Berkeley and Los Angeles, 1982.

Wilson, E., Adorned in Dreams. Fashion and Modernity, Tauris, New York, 2003. 